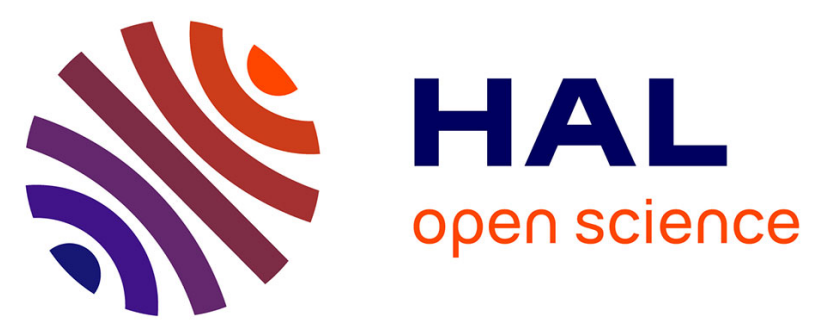

\title{
Structurally-controlled hydrothermal alteration in the syntectonic Neoproterozoic Upper Ruvubu Alkaline Plutonic Complex (Burundi): Implications for REE and HFSE mobilities
}

Sophie Decrée, Philippe Boulvais, Corentin Cobert, Jean-Marc Baele, Gilbert

Midende, Véronique Gardien, Luc Tack, Gérard Nimpagaritse, Daniel

Demaiffe

\section{- To cite this version:}

Sophie Decrée, Philippe Boulvais, Corentin Cobert, Jean-Marc Baele, Gilbert Midende, et al.. Structurally-controlled hydrothermal alteration in the syntectonic Neoproterozoic Upper Ruvubu Alkaline Plutonic Complex (Burundi): Implications for REE and HFSE mobilities. Precambrian Research, 2015, 269, pp.281-295. 10.1016/j.precamres.2015.08.016 . insu-01186043

\section{HAL Id: insu-01186043 \\ https://hal-insu.archives-ouvertes.fr/insu-01186043}

Submitted on 24 Aug 2015

HAL is a multi-disciplinary open access archive for the deposit and dissemination of scientific research documents, whether they are published or not. The documents may come from teaching and research institutions in France or abroad, or from public or private research centers.
L'archive ouverte pluridisciplinaire HAL, est destinée au dépôt et à la diffusion de documents scientifiques de niveau recherche, publiés ou non, émanant des établissements d'enseignement et de recherche français ou étrangers, des laboratoires publics ou privés. 
5 Sophie Decrée ${ }^{1,2, *}$, Philippe Boulvais ${ }^{3}$, Corentin Cobert ${ }^{4}$, Jean-Marc Baele ${ }^{4}$, Gilbert Midende ${ }^{5}$,

6 Véronique Gardien ${ }^{6}$, Luc Tack $^{2}$, Gérard Nimpagaritse ${ }^{2}$, Daniel Demaiffe ${ }^{7}$

7

$8 \quad{ }^{1}$ Royal Belgian Institute of Natural Sciences, Brussels (Belgium)

$9 \quad{ }^{*}$ Corresponding author: sophie.decree@naturalsciences.be

$102{ }^{2}$ Royal Museum for Central Africa, Tervuren (Belgium). E-mail: luc.tack@africamuseum.be;
Structurally-controlled hydrothermal alteration in the syntectonic Neoproterozoic Upper Ruvubu Alkaline Plutonic Complex (Burundi): implications for REE and HFSE mobilities

$$
\text { gerard.nimpagaritse@africamuseum.be }
$$

${ }^{3}$ Géosciences Rennes - UMR 6118 - Université de Rennes 1 (France). E-mail : philippe.boulvais@univ$\underline{\text { rennes1.fr }}$

${ }^{4}$ University of Mons (Belgium). E-mail: jean-marc.baele@umons.ac.be; corentin.cobert@umons.ac.be

${ }^{5}$ Université du Burundi. E-mail: midendegilbert@yahoo.com

${ }^{6}$ LGL :TPE UMR5276, Université Lyon 1 (France). E-mail: vgardien@univ-lyon1.fr

${ }^{7}$ Géochimie (CP 160/02), Université Libre de Bruxelles (Belgium). E-mail : ddemaif@ulb.ac.be

\section{Abstract}

The Neoproterozoic Upper Ruvubu Alkaline Plutonic Complex (URAPC), Burundi, is located along the western branch of the East African Rift. It comprises oversaturated and undersaturated syenites and a shallow level carbonatite body (the Matongo carbonatite) that does not outcrop but has been sampled by drill-cores. The elliptic map contour of the URAPC 
1 points to a syntectonic emplacement. Large shear zones that were active during magmatic

2 emplacement have accommodated a regional NE-SW shortening. Mineralization features of

3 late-magmatic to hydrothermal origin are associated with the carbonatite, which, by itself,

4 contains a dense network of calcitic veins. HFSE mineralization occurring as zircon and

5 ilmenite megacrysts can be found in an area of intense and extensive K-fenitization, which

6 lead to the transformation of the surrounding syenite into a dominant K-feldspar + biotite

7 mineral assemblage (Inamvumvu area). Carbonatitic dykes (overprinted by a hydrothermal

8 alteration) are present a few kilometers north of the Matongo carbonatite, within highly

9 deformed zones in the syenite. These dykes occur along with Na-fenites (resulting from the

10 transformation of the feldspathoidal syenite into an albite-dominant paragenesis) and are

11 enriched in REE-minerals (monazite and ancylite-(Ce)). Many magmatic (pegmatoid) dykes

12 and hydrothermal (quartz+hematite) veins also occur in shear zones in the URAPC. Most of

13 them can be interpreted as tension gashes. The chondrite-normalized REE patterns of some

14 carbonatite whole rock samples are highly disturbed, in relation to post-magmatic

15 hydrothermal alteration. The HFSE and REE distribution in the minerals from the

16 hydrothermal veins/dykes (calcitic veins within the carbonatite, carbonatite dykes overprinted

17 by a hydrothermal alteration in deformed zones, and zircon and ilmenite megacrysts) attests

18 for a complex behaviour of REE during alteration. Oxygen and carbon isotope compositions

19 of the Matongo carbonatite and the carbonatitic dykes have a magmatic signature, with $7.2<$

$20 \delta^{18} \mathrm{O}$ (vs. SMOW) $<8.5 \%$ and $-4.7<\delta^{13} \mathrm{C}$ (vs. PDB) $<-5.4 \%$ in agreement with the $\mathrm{Sr}$

21 isotopic composition. The oxygen isotope composition of zircon and ilmenite megacrysts

$22\left(\delta^{18} \mathrm{O}_{\mathrm{Zr}}=4\right.$ to $4.7 \%$, $\delta^{18} \mathrm{O}_{\mathrm{Ilm}}=-4.3$ to $-1.5 \%$ respectively) also point to a magmato-

23 hydrothermal origin of the forming fluids. Some samples of the Matongo carbonatite and the

24 carbonatitic dykes, with high $\delta^{18} \mathrm{O}$ values $\left(\delta^{18} \mathrm{O}=8.6\right.$ to $21.8 \%$ ), show evidence of a

25 medium- to low-temperature hydrothermal alteration event by an aqueous fluid. Calcitic 
1 veins in the carbonatite record another alteration event, outlined by the co-variation of $\delta^{18} \mathrm{O}$

2 and $\delta^{13} \mathrm{C}$ values $\left(\delta^{18} \mathrm{O}=16.3\right.$ to $24.7 \%$ and $\delta^{13} \mathrm{C}=-4.7$ to $0.2 \%$ ), implying the involvement

3 of a mixed $\mathrm{H}_{2} \mathrm{O}-\mathrm{CO}_{2}$ fluid. As a whole, the circulation of fluids in the URAPC was initiated

4 during magmatic emplacement and the geometry of this circulation was controlled by the

5 syn-emplacement crustal scale shear zones. Element mobility, one expression of which being

6 the mineralization features described here, follow the same scheme.

8 Keywords: Alkaline complex, carbonatite, syn-tectonic magmatism, stable isotopes, 9 Neoproterozoic, mineralization

\section{Introduction}

Alkaline massifs are composite magmatic intrusions. They are commonly enriched in 13 a number of strategic elements, among which Rare Earth Elements (REE) and High Field 14 Strength Elements (HFSE) (Chakmouradian, 2006; Pell, 1996; Mitchell, 2014; Wall and Mariano, 1996). Magmatic processes may lead to economic concentrations of these metals 16 (Chakhmouradian, 2006; Chakhmouradian and Zaitsev, 2012; Wyllie et al., 1996). In 17 addition, fluid-rock interaction at the time of emplacement can also account for high metal 18 concentrations in veins or metasomatic rocks (Gieré, 1996; Williams-Jones et al., 2012). The 19 source of fluids involved is variable from purely magmatic (fluids exsolved from melts 20 predominantly at late stages) to metamorphic (fluids released by dehydration decarbonation 21 of country rocks). Surface-derived fluids (of marine or continental origin) may be introduced 22 in the systems, especially if emplacement occurred at shallow depth..

As a general rule, alkaline massifs display a magmatic zonation at the scale of the 24 pluton, with, from the edge to the centre, saturated series (granites and syenites), 
1 undersaturated series (foidal syenites, ijolites) and often a carbonatite body (e.g., Platt, 1996).

2 Because the emplacement of these massifs is commonly atectonic, i.e. they emplace in areas

3 devoid of regional deformation, their cartographic contour and the contact between the

4 magmatic units are generally circular (e.g. Andersson et al., 2013; Bonin and Giret, 1985;

5 Bowden, 1985).

6 The Upper Ruvubu Alkaline Plutonic Complex (URAPC, Burundi) displays a

7 classical magmatic assemblage but can be distinguished from other alkaline massifs by two

8 geometric features: its outstanding dimensions $(\sim 25 \times 10 \mathrm{~km})$ and its elliptic map contour

9 (Tack et al., 1984; Midende et al., 2014). Here we argue that these characteristics relate to the

10 syntectonic emplacement of the URAPC, which was accommodated by the development of

11 large shear zones, in the overall extensional tectonic regime occurring at that time in Central

12 Africa and related to the Rodinia breakup (Burke et al., 2003; Hanson, 2003; Tack et al., 13 1996).

14 In this paper, together with structural description, we provide (1) a petrographic study 15 of the Matongo carbonatite samples, including those showing evidences of fluid-rock 16 interaction (with the occurrence of calcitic veins), (2) in situ geochemical analysis of the 17 mineral phases representative of the alteration and mineralization events, using electron 18 microprobe and laser ablation LA-ICP-MS (REE signatures) and (3) C and O isotope 19 compositions of these mineral phases as well as of the Matongo primary carbonatites. We 20 show that the Matongo carbonatite experienced interaction with fluids of variable origins, 21 focused in shear zones on a kilometric scale, which resulted in the mobility of elements, some 22 of which possibly leading to economic concentrations. More precisely, this paper will focus 23 (1) on exceptional mineralization features, i.e. several cm-wide zircon and ilmenite 24 megacrysts (HFSE enriched), which are hosted within a kaolinite deposit (and the overlying 25 laterite) in the vicinity of the Matongo carbonatite, and (2) on REE mineral occurrences 
1 found in association with carbonatitic dykes, at $\sim 3-4 \mathrm{~km}$ to the north of the Matongo

2 carbonatite. Besides, the URAPC also hosts economic phosphate deposits (occurring at the

3 top of the Matongo carbonatite), of which the reserves were estimated at $40 \mathrm{Mt}$, with an

4 average grade of $4.6 \% \mathrm{P}_{2} \mathrm{O}_{5}$, and with $17.3 \mathrm{Mt}$ of richer ore averaging $11 \% \mathrm{P}_{2} \mathrm{O}_{5}$ (considering

5 a cut-off grade at $5 \%$ and $1.5 \mathrm{~m}$ of minimum thickness; Notholt, 1999, in DFID report 2002).

6 Moreover, at the scale of the massif, pyrochlore showings have been recognized in the

7 feldspathoidal syenite (that constitutes the undersaturated series), and large idiomorphic

8 crystals of monazite - up to $2 \mathrm{~cm}$ have been found in alluvial deposits of the Tshogo area

$9 \quad$ (Fig. 1A).

\section{Geological setting}

The Neoproterozoic URAPC is located along the western branch of the East African

13 Rift in Burundi. It is emplaced in Mesoproterozoic metasedimentary rocks (Akanyaru

14 Supergroup) of the Karagwe-Ankole Belt (KAB; Fernandez-Alonso et al., 2012). Three

15 generations of granite intrude the rocks of the Akanyaru Supergroup, respectively at $\sim 1375$

$16 \mathrm{Ma}, \sim 1205 \mathrm{Ma}$ and $\sim 986 \mathrm{Ma}$ (Tack et al., 2010).

17 At $\sim 750 \mathrm{Ma}$, about twenty alkaline plutons - including the URAPC - were emplaced

18 along lithosphere-scale shear zones, located on both sides of the present-day Western Rift

19 (Tack et al., 1996). They seem to reflect uprise of mantle-derived magmas along lithospheric

20 weakness zones in relation with the breakup of Rodinia (Burke et al., 2003; Hanson, 2003;

21 Kampunzu et al., 1997; Tack et al., 1984, 1996). In such scheme, the URAPC corresponds to

22 one of the last episodes of the magmatic activity associated with Rodinia breakup, before the

23 "renewal" of alkaline/carbonatitic activity during the Cretaceous in Central Africa (e.g., 
1 Chilwa in Malawi; Simonetti and Bell, 1994), in relation with the develoment of the East

2 African rift system (Midende et al., 2014).

3 The URAPC is made up of two major bodies (units) of silicate rocks and one

4 subsurface carbonatite body, with a lens shape, the Matongo carbonatite (Fig. 1A). The NW-

5 SE elongated "outer unit" of the URAPC comprises an intimate association of saturated

6 plutonic rocks, ranging in composition from olivine-bearing gabbro and diorite to granite and

7 quartz syenite. The N-S trending ellipsoidal inner unit cross-cuts the contact between the

8 outer unit and the country rocks (Fig. 1A), and thus emplaced (even slightly) after the outer

9 unit. It is mostly composed of feldspathoidal syenite. Numerous dykes of feldspathoidal

10 syenite intrude the "outer unit", especially in its western part (where they are oriented N40).

11 In the central part of the URAPC, the Matongo carbonatite has been recognized by drilling. A

12 phosphate-rich horizon caps the carbonatite (Kurtanjek and Tandy, 1989). The Matongo

13 carbonatite has a lens shape with a long axis roughly oriented $\mathrm{N} 10^{\circ}$.

14 For the "outer magmatic unit", $\mathrm{U}-\mathrm{Pb}$ on zircon fraction and zircon $\mathrm{Pb}$-evaporation 15 ages at $748 \pm 2 \mathrm{Ma}$ and $741 \pm 2$ Ma respectively (Tack et al., 1995) have been obtained. $\mathrm{Rb}$ -

16 Sr whole rock isochron on the same unit yielded an age of $707 \pm 17 \mathrm{Ma}$ (Tack et al., 1984).

17 This age is, within uncertainty, undistinguishable from the $\mathrm{Rb}-\mathrm{Sr}$ isochron age of the "inner 18 magmatic unit" $(699 \pm 13 \mathrm{Ma}$; Tack et al., 1984) and with the $\mathrm{Pb}-\mathrm{Pb}$ isochron of the 19 carbonatite body (690 $\pm 32 \mathrm{Ma}$; Demaiffe, 2008). U-Pb on bulk zircon on the "inner unit" of 20 the URAPC however gave an age of $739 \pm 7$ Ma (Tack et al., 1984).

21 Obviously, there are important age discrepancies (30-40 Ma) relating the 22 emplacement of the URAPC. The data presented in this paper support a syntectonic 23 emplacement of the URAPC massif, what is hardly compatible with a $\sim 30$ Ma time span.

24 Most of the ages obtained on the URAPC are seemingly not accurate and do not allow to 25 interpret properly the magmatic history of the complex in terms of timing. Nevertheless, a 
1 LA-ICP-MS U-Pb age on the zircon megacrysts, at $705.5 \pm 4.5 \mathrm{Ma}$ (obtained by Midende et

2 al., 2014; see below), constitutes a reliable milestone for the URAPC emplacement. The $\mathrm{Sr}$ and $\mathrm{Nd}$ isotope compositions obtained on the Matongo carbonatites, fenites

$4 \quad\left({ }^{87} \mathrm{Sr} /{ }^{86} \mathrm{Sr}: 0.7028-0.7040\right.$, initial eNd values: $+0.2-+5.2$; Demaiffe, 2008$)$ and a few rocks

5 from the inner and outer units (with initial eNd values varying between $+1.7 \pm 1$ and $+2.3 \pm$

$6 \quad 1.5$, and initial ${ }^{87} \mathrm{Sr} /{ }^{86} \mathrm{Sr}$ comprised between 0.7025 and 0.7030 ; Tack et al., 1984) point to a

7 cogenetic relation between the Matongo carbonatite and the URAPC feldspathoidal syenites

8 (Tack et al., 1984). They also strongly support a mantle origin for the parental magma of the

9 URAPC rocks (mantle source intermediate between the DM and the EM I and II; Demaiffe, 10 2008), without any evidence for significant assimilation of crustal material (Tack et al.,

11 1984). Further studies are however needed to reinterpret the genetic history of this complex

12 massif. About $3.5 \mathrm{~km}$ to the north of the carbonatite body, carbonatitic dykes (overprinted by

13 a hydrothermal event) made up of calcite, apatite and biotite cut across the deformed

14 feldspathoidal syenite body, and are supposed to be linked to the main carbonatite body

15 (Tack et al., 1984). This suggests that the carbonatitic activity is terminal compared to syenite emplacement in the building of the URAPC massif.

In addition, in the Inamvumvu area (located between the subsurface carbonatite body and the carbonatitic dykes (Fig. 1B), numerous megacrysts of idiomorphic zircon (up to 6 $\mathrm{cm}$ ) and tabular ilmenite (up to $10 \mathrm{~cm}$ ) are disseminated in a lateritic crust and kaolinized zones developed on the quartz syenite. The zircon megacrysts are thought to result from the circulation of alkaline pegmatitic fluids associated with the emplacement of the carbonatitefeldspathoidal syenite (Fransolet and Tack, 1992). Trenching during carbonatite exploration works in the 1980s (British Sulphur Company, unpublished internal report), exposed zircon

24 megacrysts in "pegmatitic-like" dyklets intruding supergene weathered rock with preserved original coarse-grained "granitic" texture (Nkurikiye, 1989; Tack, unpublished data). These 
1 zircon crystals have been dated at $705.5 \pm 4.5 \mathrm{Ma}$ (U-Pb concordant age, Midende et al.,

2 2014) and can be related to the carbonatite late magmatic or magmato-hydrothermal

3 evolution. Indeed, the ubiquitous primary calcite, magnesian calcite, and nahcolite inclusions

4 present in these zircon megacrysts (Burke, 1998) argue for the carbonatitic affinity of these

5 minerals (Fransolet and Tack, 1992).

\section{Sampling and analytical techniques}

Several types of samples have been studied. Whole rocks carbonatite (21 samples)

9 were collected in the 1980ies's by Tack and stored at the Royal Museum for Central Africa

10 (RMCA), Tervuren (Belgium). Five other samples were collected in the carbonatitic dyke

11 zone (RG 144739, RG 144742, RG 144748, RG 144751 and RG 144752). An additional

12 sample was collected in the field in February 2014. Five drill cores (MAT 1 to 5) from the

13 Matongo carbonatite body were selected among 9 drill cores (56 to $291 \mathrm{~m}$ depth) obtained

14 from an exploration campaign (British Sulphur) in the 1980's. These cores come from the

15 rock collection of the RMCA, Tervuren. Boreholes for the 10 drill cores (S1 to S8, and ITS 3,

164 and 5) are localized on Figure 1B. Two zircon (Zr1 and Zr2) and ilmenite (Ilm1 and Ilm 2)

17 megacrysts were collected in the Inamvumvu kaolin quarry and in the Inamvumvu laterite.

18 The petrographic description is based on optical microscopy and scanning electron

19 microscopy (SEM) with energy-dispersive spectroscopy (EDS). Cathodoluminescence (CL)

20 was performed at the University of Mons (Belgium) using a cold-cathode CL unit model Mk5

21 operated at $15 \mathrm{kV}$ beam voltage and $500 \mu \mathrm{A}$ current (Cambridge Image Technology

22 Limited). CL spectra were recorded with a CITL optical spectrometer model COS8200

23 allowing acquisition from 380 to $1100 \mathrm{~nm}$ at $3.7 \mathrm{~nm}$ resolution. SEM-CL micrographs and

24 spectra were acquired with a cooled-CCD camera and a spectrometer mounted on the optical 
1 block of a Cameca SX51 Electron Probe Micro-Analyzer (EPMA) operated at $15 \mathrm{kV}$ and 20 $2 \mathrm{nA}$.

3

4 ICP-MS at the RMCA, Tervuren. Quantitative mineral EPMA analyses were acquired using a

5 Cameca SX51 electron microprobe operated at $15 \mathrm{kV}$ and $20 \mathrm{nA}$ (Tables 1-6 in supplementary material). This microprobe is equipped with four wavelength-dispersive

7 (WDS) spectrometers and standard LiF, PET, TAP and PCs crystals. The laser ablation ICP-

8 MS measurements (Tables 2-7 in supplementary material) were performed at the RMCA,

9 Tervuren. A New-Wave UP-193 FX fast excimer (193nm) laser coupled with a Thermo

10 Scientific X-Series2 quadrupole ICP-MS was used. The laser was run at $50 \mathrm{~Hz}$ and a fluence

11 of $10 \mathrm{~J} / \mathrm{cm}^{2}$ for $100 \mu \mathrm{m}$ or $30 \mu \mathrm{m}$ spot size. He gas at a flow rate of $0.65 \mathrm{l} / \mathrm{min}$ was flushed

12 into the ablation cell and was mixed after the cell with Ar carrier gas at a flow rate of 0.76

$131 /$ min. Several internal standards have been used for correcting instrumental drift and ablation

14 rate, depending on the analysed mineral phases: ${ }^{43} \mathrm{Ca}$ for carbonates and fluorapatite, ${ }^{29} \mathrm{Si}$ for 15 zircon, ${ }^{47} \mathrm{Ti}$ for ilmenite and ${ }^{140} \mathrm{Ce}$ for monazite and ancylite-(Ce). The NIST SRM 614, 612 16 and 610 were used as external standards and were measured frequently during the course of 17 the analyses. The precision at 1 sigma level on the NIST SRM 612 is $\sim 10 \%$ RSD. The ablation patterns were smooth, except for ilmenite that contains inclusions.

The $\mathrm{C}$ and $\mathrm{O}$ isotope compositions (Table 8 in supplementary material) have been obtained at the University of Rennes 1 (France) and at the University of Lausanne

21 (Switzerland). At Rennes, the oxygen isotope compositions of silicates and oxides were 22 obtained by the conventional fluorination method (after Clayton and Mayeda, 1963).

23 Representative samples of large populations of zircon and ilmenite megacrysts were selected,

24 cleaned, washed and crushed into a fine-grained powder. O isotope values thus correspond to 25 whole grains compositions. The powder was reacted with $\mathrm{BrF} 5$ at $680-700^{\circ} \mathrm{C}$ for 12 hours 
1 and the liberated $\mathrm{O}_{2}$ converted into $\mathrm{CO}_{2}$ by reaction with hot graphite. $\mathrm{C}$ and $\mathrm{O}$ isotope

2 compositions of carbonates were measured on whole rocks powders (21 samples of

3 carbonatite) and on powders recovered by micro-drilling on drilled cores (micro-drillings are

4 shown by red lines in Fig. 4). Carbonate powders were reacted with anhydrous

5 orthophosphoric acid in vessels at $50^{\circ} \mathrm{C} \cdot \mathrm{CO}_{2}$ isotope compositions were measured on a VG

6 SIRA 10 triple collector mass spectrometer. The analytical uncertainty is $\pm 0.2 \%$ for $\mathrm{O}$ in

7 silicates, oxides and carbonates, and $\pm 0.1 \%$ for $\mathrm{C}$ in carbonates; it was estimated using

8 replicate analysis of some samples and reproducibility of standards, both international (NBS

928 and NBS 19) and in-house (Prolabo Rennes and A1113) standards. At Lausanne, the C

10 and $\mathrm{O}$ isotope composition of the carbonates (20 to $40 \mathrm{mg}$ of rock powder) was there

11 measured with a GasBench II connected to a Finnigan MAT DeltaPlus XL mass

12 spectrometer, using a He- carrier gas system according to a method adapted after Spoetl and

13 Vennemann (2003). Sample values were normalized using an in-house Carrara Marble

14 standard calibrated against $\mathrm{V}_{\mathrm{PDB}}$ for both carbon and oxygen isotope compositions and

15 recalculated to the $\mathrm{V}_{\text {SMOW }}$ scale for $\delta^{18} \mathrm{O}$ values of carbonates standard calibrated against $\delta^{13} \mathrm{C}$

16 and $\delta^{18} \mathrm{O}$ values of NBS-19 $(+1.95 \%$ and $2.20 \%$, relative to Vienna Pee Dee Belemnite

17 (VPDB)). External reproducibility estimated from replicate analyses of the in-house standard

18 (n=11) is $\pm 0.1 \%$ for both $\delta^{13} \mathrm{C}$ and $\delta^{18} \mathrm{O}$.

\section{Structure of the URAPC}

The Upper Ruvubu Alkaline Plutonic Complex (URAPC) defines an elliptic map

22 contour, with a long axis oriented NW-SE. This shape corresponds actually to the outer unit,

23 the inner unit being more N-S orientated. The Matongo carbonatite is located at the contact

24 between the inner unit and the host metasediments that form a N-S to N10 ${ }^{\circ}$ indentation on the 
1 eastern edge of the carbonatite (Fig. 1). The carbonatite body itself has an elliptic shape, with

2 a long axis oriented $\mathrm{N} 10^{\circ}$.

3 The regional foliation is globally vertical. It is overall parallel to the long axis of the

4 elliptic-shaped outer unit, striking NW-SE along the south-western edge of the Massif.

5 Within the URAPC, the foliation of the outer unit is parallel to the regional foliation. This is

6 also the case for the inner unit but solely in the southern part (south of Kiziba, Fig. 1A). In

7 the northern part of the inner unit, foliation planes display a curved pattern, parallel to the 8 external contact.

9 To the south, close to the Matongo carbonatite, the intrusion is hidden by 10 metasediments that form a N-S to $\mathrm{N} 10^{\circ}$ elongated cartographic shape. The intrusive contact 11 between metasediments and the Buraniro Granite (Fig. 2A, location on Fig. 1A) is well 12 exposed on the field. It is marked by a strain gradient in the granite, with undeformed granite 13 about $100 \mathrm{~m}$ away from the contact, remarkable $\mathrm{C} / \mathrm{S}$ fabrics $20 \mathrm{~m}$ away from the contact (both 14 shear and foliation planes are vertical) and mylonitic fabrics at the contact. The stretching 15 lineation is plunging to the north, between $30^{\circ}$ in the $\mathrm{C} / \mathrm{S}$ structure facies to vertical in the 16 mylonite. Kinematics criteria point to a dextral component in the horizontal plane (Fig. 2A, 17 second photo) and sagging of the metasedimentary block (Fig. 2B, third photo). In the 18 metasediments close to the contact, sediment layering is parallel to the foliation which is 19 vertical and parallel to the contact. The stretching lineation, marked notably by andalusite 20 grains (Fig. 2B), is vertical. At $300 \mathrm{~m}$ westward within the metasedimentary unit, foliation is 21 oblique to sediment layering. From these structural and metamorphic features, we infer that 22 the contact between sediments and the outer unit is a large zone of deformation that was 23 active during magmatic emplacement.

Other areas of high strain zones have been observed in the field, and are indicated in

25 Fig. 1A together with the sense of shear in the horizontal plane. In the deformed zones, which 
1 commonly display a mylonitic fabric, the stretching lineation constantly plunges towards the

2 north at about $30^{\circ}$, reaching locally a vertical dip locally similar to that observed at the

3 intrusive contact. These deformed zones are mostly present in the outer unit and locally in the

4 eastern part of the inner unit, north and north-east of Kiziba. In the outer unit, along the road

5 between Matongo and Kayanza, a strong kaolinization of quartz syenite has developed in the 6 mylonitic zones.

7 In the north-western part of the outer unit, numerous meter-large dykes outcrop in the 8 host metasediments; they are oriented $\mathrm{N} 30^{\circ}$ to $\mathrm{N} 50^{\circ}$. One of these dykes is folded with nearly 9 vertical fold axes. The internal schistosity of the dyke defines a fan-like pattern (Fig. 2C) 10 around the general NW-SE direction.

\section{Evidence for fluid-rock interactions in the URAPC}

\subsection{Field observations}

Besides the variety of magmatic rocks occurring in the URAPC, the massif comprises several features testifying for magmato-hydrothermal fluid circulations.

In the south-western part of the outer unit, north-east of Buraniro, a large quartz vein outcrops. It is oriented $\mathrm{N} 40^{\circ}$ and is at least $100 \mathrm{~m}$ long and about 20 meters wide. Quartz grains within the vein are fractured but no particular fractures orientation or fabrics can be measured. About $6 \mathrm{~km} \mathrm{NE}$ of Matongo, quartz blocks disseminated by the local population along the roads for building purpose, display a remarkable deformation with hematite crystals

21 growing along shear planes during deformation (Figs. 3A,B). The two types of quartz veins

22 formed syn-tectonically, and display a geometric and genetic affinity with the silica-saturated outer unit. 
Albite veins (Fig. 3C) and carbonatitic dykes, overprinted by a hydrothermal

2 alteration, are present at about $3.5 \mathrm{~km}$ north of the Matongo carbonatite body, in the

3 feldspathoidal syenite (Fig. 1B). They are usually present as pluridecimetric to metric lenses

4 (Figs. 3D, E). They are hosted in highly deformed feldspathoidal syenite and have an

5 orientation roughly perpendicular to the foliation and the stretching lineation in the syenite.

6 Thus, they can be interpreted as tension gashes. The host feldspathoidal syenite is locally Na-

7 fenitized (transformation of nepheline into albite; as shown in Drüppel et al., 2005) and

8 brecciated close to the carbonatite injections. The carbonatitic dykes, which are $\mathrm{cm}$ - to dm-

9 large, contain variable amounts of angular to sub-rounded clasts, which gives a breccia

10 texture to the dykes. They are whitish or pinkish in color and predominantly made up of Na-

11 fenitized wall-rock (Fig. 3E). The dyke matrix predominantly comprises carbonates, biotite,

12 albite and Fe-sulfides (pyrite and pyrrhotite).

In the vicinity of the carbonatitic dykes (Fig. 1B), pegmatoid dykes made up of

14 nepheline, sodalite and cancrinite are located within deformed zones of the feldspathoidal

15 syenite. These pegmatoidic dykes correspond also to tension gashes in the zones of high

16 strain (Fig. 3F). Similar mineral assemblage (with Ti-magnetite) is present in mylonitic zones

17 located within the nearby quartz syenite as infillings of en-echelon sigmoidal tension gashes

18 (up to $30 \mathrm{~cm}$ in length, Fig. 3H). These dykes/veins point to fluid circulation during both

19 magmatism (they have a clear genetic affinity with the under-saturated inner unit considering

20 the similar mineral assemblage) and deformation (they occur as tension gashes within zones

21 of high strain). Finally, the zircon and ilmenite megacrysts (Figs. 3I-K), which occur in

22 "pegmatitic-like" veinlets/dyklets crosscutting the quartz syenite also testify for magmato-

23 hydrothermal circulations. The strong development of kaolinization (mostly due to the

24 transformation of orthoclase: $3 \mathrm{KAlSi}_{3} \mathrm{O}_{8}+2 \mathrm{H}^{+}=3 \mathrm{Al}_{2} \mathrm{Si}_{2} \mathrm{O}_{5}(\mathrm{OH})_{4}+2 \mathrm{~K}^{+}$; Manning, 1995) is

25 documented in mylonitic zones. This is consistent with mineralogical criteria that point to an 
1 initial kaolinite crystallization under hydrothermal conditions (Nkurikiye, 1989), even though

2 such an early kaolinization can be debated. At the least, the present kaolinization emphasizes

3 an earlier phase of K-fenitization, with subsequent formation of orthoclase, which is easily

4 transformed into kaolinite later on. Thus, as a whole, regardless of the nature of the magmatic

5 fluid (genetically related to the saturated outer unit, to the under-saturated inner unit or to the

6 carbonatite body), magmato-hydrothermally derived fluid circulation was synchronous to 7 regional deformation.

9 5.2. Fluid-rock interactions in the Matongo carbonatite

10 The petrographic and mineralogical characteristics of the different facies of the

11 Matongo carbonatite body have been described by Midende et al. (2014). Coarse- and fine-

12 grained calciocarbonatite (sövite I and II, respectively), which contains vanadiferous aegirine

13 (partly transformed in amphibole) and apatite in various amounts (up to cumulates), and

14 ferrocarbonatite have been identified. Calcite veinlets that crosscut the coarse-grained altered

15 calciocarbonatite have been interpreted as representing a late hydrothermal event, compared

16 to the magmatic activity (Midende, 1984; Midende et al., 2014). K-fenitization, resulting in

17 the transformation of the host rock in a dominant K-feldspar and biotite mineral assemblage,

18 is also well developed in the external part of the carbonatite (Midende, 1984).

19 In the studied drill-cores, a dense network of calcite veins is visible (Fig. 4). These

20 veins are variable in colour, from clear white to grey. They are mostly calcitic, but locally

21 iron oxides and euhedral dolomite crystals are present (see bottom of the large white vein in

22 core MAT 3, Fig. 4). The veins draw complex cross-cutting relationships (e.g. core MAT 1a,

23 Fig. 4), which attests of superposed fluid activities under brittle conditions. Interestingly, core 
1 MAT 3 displays a well-defined foliation that results from ductile deformation of the

2 carbonatite. On the contrary, magmatic fabric is visible in core MAT 2 (Fig. 4).

\section{Petrographic and mineralogical description}

5

6

7

\subsection{Carbonatitic dykes and breccia}

In the carbonatitic dykes, the matrix predominantly comprises carbonates (generally as euhedral crystal aggregates, described below), biotite (as laths up to $1 \mathrm{~cm}$ in length), euhedral albite crystals (up to $2 \mathrm{~mm}$ in size) and Fe-sulfides (pyrite and pyrrhotite). These dykes are locally brecciated and contain clasts of more or less deeply metazomatized (=fenitized) former feldspathoidal syenite. A detailed description of the most fenitized clasts and of the complex breccia matrix in which they are embedded is given below.

\subsubsection{Clasts}

The most fenitized clasts consist mainly of albite, variably invaded by carbonates. Albite grains present fine- to coarse-grained textures (with euhedral crystals up to $500 \mu \mathrm{m}$ ) and are locally cloudy (slightly silicified, Fig. 5A). Euhedral laths of Ba-rich muscovite (1.3-2 \% $\mathrm{BaO}$, Table 1) are present as tiny veins (from $100 \mu \mathrm{m}$ to $3 \mathrm{~mm}$ width) crosscutting the clasts (Figs. 5A, B). These veins are commonly surrounded by a Fe oxide-rich halo. Muscovite also replaces biotite (with the following reaction: $\mathrm{KMg}_{3}\left(\mathrm{AlSi}_{3} \mathrm{O}_{10}\right)(\mathrm{OH})_{2}+2 \mathrm{Al}^{3+}=$ $\mathrm{KAl}_{2}\left(\mathrm{AlSi}_{3} \mathrm{O}_{10}\right)(\mathrm{OH})_{2}+3 \mathrm{Mg}^{2+} ;$ Stoch and Sikora, 1976), with a Ba-rich biotite $(1.3 \% \mathrm{BaO}$, Table 1) as an intermediate product (Fig. 5C). In the clasts, biotite laths (up to $200 \mu \mathrm{m}$ in length) occur as complex aggregates interstitial between albite and a Fe-Mn-rich calcite, named calcite 1 hereafter. Biotite is frequently associated with (1) ilmenite and rutile intergrowths (Fig. 5C), (2) euhedral zoned and blue-luminescing fluorapatite (typically several hundreds of $\mu \mathrm{m}$ in section; Fig. 5D), (3) euhedral, blue-green luminescing zircons 
1 (from several $\mu \mathrm{m}$ to $1 \mathrm{~mm}$ in size), slightly enriched in $\mathrm{Hf}$, Ta, Th and U (Table 5), and (4)

2 small (up to several $\mu \mathrm{m}$ in size) betafite grains. The CL of apatite is activated mainly by the

3 LREE Sm ${ }^{3+}, \mathrm{Nd}^{3+}$ and $\mathrm{Eu}^{2+}$ together with $\mathrm{Mn}^{2+}$ (Kempe and Götze, 2002; Waychunas, 2002).

4 Ilmenite and zircon are also found as isolated crystals in the clasts. Small barite aggregates

5 (up to a few tens of $\mu \mathrm{m}$ in size) and euhedral pyrite crystals (up to $1 \mathrm{~mm}$ in section) are 6 observed in the most fenitized clasts.

The matrix of the carbonatitic dykes predominantly consists of microgranular (up to

9 several $\mathrm{mm}$ in size) calcite $1(2-2.4 \% \mathrm{FeO}$; Table 2$)$ with minor ferroan dolomite $(27.5 \%$

$10 \mathrm{CaO}, 13.3 \% \mathrm{FeO}, 11.2 \% \mathrm{MgO}$, Table 2 ). The calcite 1 is partly replaced by a nearly pure

11 calcite - named calcite 2 hereafter (see analyses Table 2) - associated with $\mu$ m-wide

12 strontianite grains. This replacement is particularly well highlighted by CL images (Fig. 5D):

13 orange calcite 2 replaces a dull-luminescent calcite 1 at the edges of the crystals and along

14 cleavages. Calcite 1 and ferroan dolomite are intimately associated with subhedral crystals of

15 albite (up to $1 \mathrm{~mm}$ ), which is pink/red under CL (Fig. 5D). The dominant red emission is

16 commonly observed in feldspars occurring in fenitized rocks (Marshall, 1988). As in the

17 clasts, biotite lath aggregates (up to several $\mathrm{cm}$ in size) seem interstitial between albite and

18 calcite 1 . They are also intimately associated with ilmenite and rutile intergrowths, zircon and

19 betafite grains. In the breccia matrix, euhedral and blue-luminescing zoned fluorapatite (Fig.

20 5D), enriched in $\mathrm{Sr}(0.3-1.2 \% \mathrm{SrO}$, Table 2), apparently formed contemporaneously or

21 slightly later than biotite.

\subsubsection{REE-bearing crystals}

In the carbonatitic dykes, monazite is the most abundant REE-bearing mineral phase.

24 It typically shows a significant enrichment in Th (ranging from 1.5 to $8.3 \% \mathrm{ThO}_{2}$, Table 3) 
1 and a slight enrichment in $\mathrm{Ca}, \mathrm{Fe}, \mathrm{Sr}$ and $\mathrm{F}(0.1-0.8 \% \mathrm{CaO}$, up to $0.6 \% \mathrm{FeO}$, up to $1.8 \%$

$2 \mathrm{SrO}$ and $0.5-0.8 \% \mathrm{~F}$, Table 3). Monazite is usually present either as an interstitial phase

3 between the biotite lath aggregates (Figs. 5C), in association with the calcite 1, or as

4 subhedral crystals (up to $150 \mu \mathrm{m}$ in length) and needle-like crystal aggregates (up to $300 \mu \mathrm{m}$

5 in size), replacing albite in the clasts. Under CL, monazite exhibits a weak but distinct deep-

6 blue luminescence (Fig. 5E). The matrix of the brecciated dykes also include ancylite-(Ce),

7 which is enriched in $\mathrm{Sr}$, Th, Fe and $\mathrm{F},\left(2.1-19.8 \% \mathrm{SrO}, 1.4-3.7 \% \mathrm{ThO}_{2}\right.$, up to $2.8 \% \mathrm{FeO}$,

8 and 0.6-0.9 \% F; Table 4). Such enrichments have been documented in the carbonatitic

9 complex at Khibini and Sokli (Zaitsev et al., 1998; Al Ani and Sarapää, 2009). In the studied

10 carbonatitic breccias, this mineral phase is present as euhedral or subhedral crystals (several

11 tens of $\mu \mathrm{m}$ in length) or needle-like crystal aggregates, commonly in association with calcite

122 (Fig. 5F) and strontianite. Ancylite-(Ce) replaces albite and mucovite in the clasts (Fig. 5B)

13 or occurs as interstitial phase of the biotite aggregates (Fig. 5G).

6.2. Matongo carbonatite drill cores

The calcite veins that form the dense network observed in the drill cores (Fig. 4)

17 mostly comprise orange-luminescing calcite (Fig. 6A-C), generally slightly enriched in Mn

18 (mean value of $0.5 \% \mathrm{MnO}$, Table 2) even though it can locally show a moderate enrichment

19 in $\mathrm{Mn}, \mathrm{Fe}$ or $\mathrm{Sr}$ (up to $2.1 \% \mathrm{MnO}, 1.2 \% \mathrm{FeO}$, and $0.8 \% \mathrm{SrO}$ ). Red-luminescing dolomite

20 (Fig. 6B, D), K-feldspar, albite and fluorapatite are accessory minerals commonly associated

21 with calcite in the drill core veins.

In the MAT 3 core, affected by ductile deformation (Fig. 6c), fluorapatite occurs as

23 subhedral/ovoid crystals (several tens of hundreds $\mu \mathrm{m}$ in size) aligned parallel to the mylonitic foliation marked by carbonate twins. Under CL, a light blue rim of fluorapatite is 
1 visible around the deep-blue fluorapatite cores and develops especially on the crystal faces

2 perpendicular to the foliation. This feature indicates that the apatite overgrowth formed

3 during ductile deformation and being developed in pressure-shadow around fluorapatite

4 crystals. Locally, some apatite crystals embedded in the mylonitic carbonates are fractured, a

5 qualitative record of the large intensity of the deformation during the ductile to brittle 6 deformation.

8 6.3. HFSE mineralization - Zircon and ilmenite megacrysts

9 Megacrysts of zircon (a few mm up to six $\mathrm{cm}$ ) exhibit growth zoning that relates to 10 the variation of Th content (up to $0.6 \%$ ThO, Table 5). Zircon is also slightly enriched in Hf 11 (ranging from 0.4 to $0.8 \% \mathrm{HfO}_{2}$, Table 5) with very little (if any) enrichment in $\mathrm{U}$ (up to 0.1 $12 \% \mathrm{UO}_{2}$, Table 5).

13 Ilmenite is generally well crystallized with tabular shape and can be several $\mathrm{cm}$ wide.

14 The ilmenite from the Inamvumvu kaolin quarry is commonly weathered and pervasively 15 replaced by iron oxides/hydroxides associated to pseudorutile/leucoxene, what is usually 16 observed in case of supergene alteration (Grey and Reid, 1975; Pownceby, 2010). This 17 explains its high $\mathrm{Ti}\left(53.6-74.9 \% \mathrm{TiO}_{2}\right.$; Table 6) and low $\mathrm{Fe}$ and $\mathrm{Mn}$ contents (17.1-36.3\% 18 FeO, 0.1-0.6 \% MnO, Table 6) compared to the ilmenite megacrysts from the laterite (35.5$1949.9 \% \mathrm{FeO}, 43-53.1 \% \mathrm{TiO}_{2}, 0.1-1.3 \% \mathrm{MnO}$; Table 6). The $\mathrm{Nb}$ content varies from $\sim 450$ to $20 \sim 2000 \mathrm{ppm}$ (Table 6) and seems independent of the ilmenite weathering degree. 7. REE characteristics

23 7.1. Minerals from the carbonatitic dykes 
Regarding the REE contents (LA-ICP-MS data, see Supplementary material), the

2 carbonates (calcites 1 and 2) from the carbonatitic dykes are significantly different from the

3 whole rock carbonatite facies from the main intrusion (Fig. 7A). Despite an overall

4 enrichment in REE ( $\Sigma$ REE from 326 up to $830 \mathrm{ppm})$ and a moderate LREE enrichment $(3<$

$5 \quad \mathrm{La}_{\mathrm{N}} / \mathrm{Yb}_{\mathrm{N}}<5$ ), the calcite from the breccia exhibits variable MREE depletion (Fig. 7A), with

6 no significant $\mathrm{Ce}$ anomaly $\left(0.8<\mathrm{Ce} / \mathrm{Ce}^{*}<1.1\right)$ and a slight positive Eu anomaly $(1.1<$

$\left.7 \mathrm{Eu} / \mathrm{Eu}^{*}<1.5\right)$. The calcite representative of sample RG 144.739 is obviously less MREE-

8 depleted than those of sample RG 144.752 (Table. 2). The most MREE depleted calcite

9 patterns seem to mirror (or present opposite patterns) the one of the "late" hydrothermal 10 calcite.

Fluorapatite is strongly enriched in REEs ( $\mathrm{REE}$ from 7300 up to $11375 \mathrm{ppm}$, Table

12 2, Fig. 7A), with high $\mathrm{La}_{\mathrm{N}} / \mathrm{Yb}_{\mathrm{N}}$ ratios, ranging from 20 to 54, and neither significant Ce nor

13 Eu anomalies $\left(0.9<\mathrm{Ce} / \mathrm{Ce}^{*}<1.2,1<\mathrm{Eu} / \mathrm{Eu}^{*}<1.1\right)$.

Monazite grains from the carbonatitic breccias (Fig. 7B) are characterized by a very strong REE enrichment $\left(49.5<\Sigma \mathrm{REE}<61.8 \%\right.$, with an extreme $\mathrm{La}_{\mathrm{N}} / \mathrm{Yb}_{\mathrm{N}}$ ratio, up to 107000 (Table 3). Their patterns present moderate $\mathrm{Ce}$ and $\mathrm{Eu}$ anomalies $\left(0.6<\mathrm{Ce} / \mathrm{Ce}^{*}<0.9\right.$, $\left.0.6<\mathrm{Eu} / \mathrm{Eu}^{*}<0.8\right)$. Ancylite-(Ce) is also enriched in REE ( $\Sigma \mathrm{REE}$ ranges from 35.4 to 39.6 \%; Table 4), especially in LREEs (Fig. 7B) but the fractionation varies largely $(1203<$

$\left.19 \mathrm{La}_{\mathrm{N}} / \mathrm{Yb}_{\mathrm{N}}<33029\right)$, from grain to grain. They do not exhibit large $\mathrm{Ce}$ and $\mathrm{Eu}(0.7<\mathrm{Ce} / \mathrm{Ce} *<$ $\left.1,0.5<\mathrm{Eu} / \mathrm{Eu}^{*}<0.8\right)$ anomalies. patterns of several fluoarpatite and host calciocarbonatite (Fig. 7E). 
1 It appears that calcite from a single drill core can exhibit highly variable REE 2 signatures from grain to grain. In the MAT 1 drill core, a first calcite type (type 1 in Fig. 7C) 3 presents a LREE enrichment ( $5<\mathrm{La}_{\mathrm{N}} / \mathrm{Yb}_{\mathrm{N}}<37$; Table 7), while a second type (type 2 in

4 Fig. 7C) is characterized by concave-upward pattern, with $\mathrm{La}_{\mathrm{N}} / \mathrm{Yb}_{\mathrm{N}}$ ratios varying from 0.8 5 to 5 . Both calcite types display comparable and low total REE contents (1-86 ppm for type 1, 6 3-77 ppm for type 2), with negative $\mathrm{Ce}$ and positive Eu anomalies $(0.2<\mathrm{Ce} / \mathrm{Ce} *<1,2.8<$ $7 \mathrm{Eu} / \mathrm{Eu}^{*}<4.4$, Table 7). Similarly, in the MAT 2 drill core, two calcite types can be 8 distinguished. Type 1 (Fig. 7D) is depleted in REE $(1<\Sigma$ REE $<9)$, mostly in LREE $9\left(\mathrm{La}_{\mathrm{N}} / \mathrm{Yb}_{\mathrm{N}}\right.$ ratios ranging from 0.1 to 0.5$)$, while type 2 (Fig. 7D) is characterized by MREE 10 enriched/HREE depleted patterns $\left(1.2<\mathrm{La}_{\mathrm{N}} / \mathrm{Yb}_{\mathrm{N}}<68.2\right)$. Both types display negative Ce 11 anomalies (Ce/Ce* from 0.1 to 1$)$ and positive $\mathrm{Eu}$ anomalies $\left(3.4<\mathrm{Eu} / \mathrm{Eu}^{*}<5.1\right.$, Table 7). 12 In the MAT 3 drill core, only one pure calcite has been analyzed (Fig. 7E). It presents a 13 LREE-rich and MREE-depleted (concave-upward) pattern $\left(\Sigma \mathrm{REE}=144 \mathrm{ppm}, \mathrm{La}_{\mathrm{N}} / \mathrm{Yb}_{\mathrm{N}}=\right.$ 14 22.2), with negative $\mathrm{Ce}$ and positive Eu anomalies $\left(\mathrm{Ce} / \mathrm{Ce}^{*}=0.7, \mathrm{Eu} / \mathrm{Eu}^{*}=2.6\right.$, Table 7). On 15 the contrary, fluorapatite from the same vein is enriched in REE $(4011<\Sigma \mathrm{REE}<5996 \mathrm{ppm}$, $\left.1690<\mathrm{La}_{\mathrm{N}} / \mathrm{Yb}_{\mathrm{N}}<137\right)$, with negative $\mathrm{Ce}(\mathrm{Ce} / \mathrm{Ce} *=0.9)$ and positive $\mathrm{Eu}$ anomalies $\left(\mathrm{Eu} / \mathrm{Eu}^{*}\right.$ 17 ranging from 3 to 3.2, Table 7).

18 Calcite from the host calciocarbonatite does not present the strong enrichment in 19 LREE ( $\mathrm{REE}$ from 17 up to $122 \mathrm{ppm}, 1<\mathrm{La}_{\mathrm{N}} / \mathrm{Yb}_{\mathrm{N}}<9$ ) that is common for primary 20 carbonatites (e.g., Pell, 1996) (Fig. 7E). It shows variable Ce anomalies $(0.2<\mathrm{Ce} / \mathrm{Ce} *<2.2)$ 21 and positive Eu anomalies ranging from 3.2 to 4.4 (Table 7).

23 7.3. Zircon and ilmenite megacrysts from Inamvumvu 
2 to 0.08$)$, with a pronounced positive $\mathrm{Ce}$ anomaly $(1.3<\mathrm{Ce} / \mathrm{Ce} *<6.7)$ and no significant $\mathrm{Eu}$

3 anomaly $\left(0.6<\mathrm{Eu} / \mathrm{Eu}^{*}<1\right)$. The zircon crystals from the kaolin deposit have significantly

4 higher REE contents ( $\mathrm{REE}$ from $449 \mathrm{ppm}$ to $1855 \mathrm{ppm}$, with two exceptions at 41 and 144

5 ppm, Fig. 7F, Table 5) than those from the laterite (39 ppm $<\Sigma R E E<706 \mathrm{ppm}$ ), but the 6 patterns are quite similar.

7 Ilmenite from the Inamvumvu kaolin quarry is moderately enriched in REE ( $\Sigma$ REE:

80.4 to $64 \mathrm{ppm}$ ), with a LREE enrichment (Fig. 7G, $\mathrm{La}_{\mathrm{N}} / \mathrm{Yb}_{\mathrm{N}}: 3$ to 7), positive Ce anomaly $9\left(1.3<\mathrm{Ce} / \mathrm{Ce}^{*}<1.8\right)$ but no significant $\mathrm{Eu}$ anomaly $\left(0.7<\mathrm{Eu} / \mathrm{Eu}^{*}<1.3\right)$. This $\mathrm{REE}$ 10 enrichment is seemingly related to the abundance of iron (hydr-)oxide inclusions in this 11 weathered ilmenite. Indeed, the non-weathered ilmenites from the Inamvumvu laterites show 12 significantly lower REE contents (Fig. 7G, $\Sigma$ REE from 0.1 to $2 \mathrm{ppm}$ ), with higher $\mathrm{La}_{\mathrm{N}} / \mathrm{Yb}_{\mathrm{N}}$ 13 ratios (from 1 to 26 ) (Table 6), generally positive $\mathrm{Ce}$ anomalies $(0.8<\mathrm{Ce} / \mathrm{Ce} *<7.6)$ and 14 variable $\mathrm{Eu}$ anomalies $\left(0.6<\mathrm{Eu} / \mathrm{Eu}^{*}<2.8\right)$.

\section{Stable isotopes}

8.1. Matongo carbonatite and calcite veins

Many of the oxygen and carbon isotope compositions of the various facies of the Matongo carbonatite body (facies described in Midende et al. (2014)) are typical of magmatic carbonatites ("Taylor box"; Taylor et al., 1967; Fig. 8A): $\delta^{18} \mathrm{O}$ values are between 7.2 and

$218.5 \%$ and $\delta^{13} \mathrm{C}$ values are between -4.7 and $-5.4 \%$, Table 8). Nevertheless, several samples

22 show a significant increase of their $\delta^{18} \mathrm{O}$ value, up to $11 \%$, irrespective of their petrographic 23 nature, but their $\delta{ }^{13} \mathrm{C}$ remain unmodified. The altered coarse-grained sövite (sövite I) is 24 significantly displaced towards higher $\delta^{18} \mathrm{O}$ values (20.3 and $21.0 \%$ ) with almost unmodified 
$1 \quad \delta^{13} \mathrm{C}$ values (-4.8 and $-4.0 \%$ ). The "late" hydrothermal calcite has an extreme $\delta^{18} \mathrm{O}$ value of

$2 \quad 21.6 \%$, with a corresponding higher $\delta{ }^{13} \mathrm{C}$ value of $-1.1 \%$.

In the MAT1-5 drill cores (the location of micro-sampling is indicated by purple lines

4 in Fig. 4C), the calciocarbonatite samples have high $\delta^{18} \mathrm{O}$ values, above $16 \%$, the highest

5 value (close to 25\%) being recorded by mylonitic samples of core 3 (dots 19 and 20 on Fig.

$63 \mathrm{c}$ and Table 8). There is a general tendency in this population to display an increase in $\delta^{13} \mathrm{C}$

$7 \quad$ values together with the $\delta^{18} \mathrm{O}$ values increase.

8 This tendency is clearer for the calcite veins population, which shows an increase in

9 both the $\delta^{18} \mathrm{O}$ values (from 16.3 to $25.3 \%$ ) and the $\delta^{13} \mathrm{C}$ values (from -5.5 to $0.22 \%$ ). Only

10 three samples ( 1 calciocarbonatite and 2 calcite veins) significantly plot outside the array and

11 deviate from it by a marked increase in $\delta^{13} \mathrm{C}$ for a given $\delta^{18} \mathrm{O}$ value.

13 8.2. Carbonatitic dykes

14 The $\delta^{18} \mathrm{O}$ values of the carbonatitic dykes are between 7.3 and $12.5 \%$, with 15 corresponding $\delta{ }^{13} \mathrm{C}$ values from -5.7 to $-5.0 \%$ (Table 8). Some of these values plot in the

16 Taylor primary carbonatite box, while others are somewhat displaced towards higher $\delta^{18} \mathrm{O}$

17 values. Sample RG 144 739, which consists almost exclusively of calcite 1 (early calcite)

18 plots in the Taylor box $\left(\delta^{18} \mathrm{O}=9.7 \%\right.$ and $\delta{ }^{13} \mathrm{C}=-5.6 \%$, while sample RG 144752 ,

19 comprising the second calcite generation (calcite 2) replacing calcite 1, shows a distinct

20 signature $\left(\delta^{18} \mathrm{O}=12.5 \%\right.$ and $\delta^{13} \mathrm{C}=-5.0 \%$ )

21

22 8.3. Zircon and ilmenite megacrysts 
1 The zircon megacrysts have $\delta^{18} \mathrm{O}$ values between 4.0 and $4.7 \%$, regardless of their

2 host rock (kaolinite or laterite; Table 8). The measured range is slightly below the average

3 value for mantle zircons $\left(\delta^{18} \mathrm{O}_{\mathrm{Zr}}=5.3 \pm 0.3 \%\right.$; Valley, 2003). However, it compares well with

4 the theoretical value of zircon in equilibrium with magmatic calcite from the carbonatite

$5 \quad\left(\delta^{18} \mathrm{O}_{\mathrm{Cal}}\right.$ between 7 and $8 \%$, which is estimated between 3.6 and $5.7 \%$ using the calcite-

6 zircon fractionation factor of Zheng, 1993 and a temperature of equilibration between 400

7 and $600^{\circ} \mathrm{C}$. This temperature range has been previously used to calculate mineral-fluid

8 oxygen isotope composition for late-stage fluids from hydrothermal veins and pegmatite

9 related to carbonatite-syenite complex (Tamazeght complex, Morocco; Marks et al., 2009).

10 Ilmenite shows more widespread $\delta^{18} \mathrm{O}$ values between -1.5 and $-4.3 \%$, with the lowest value

11 at $-4.3 \%$ obtained in ilmenite from Kaolin and the highest values at -1.5 and $-1.7 \%$ obtained

12 in two grains from the ferriferous laterite (Table 8) respectively. The theoretical value of

13 ilmenite in equilibrium at $400-600^{\circ} \mathrm{C}$ with the carbonatite body $\left(\delta^{18} \mathrm{O}_{\mathrm{Cal}}=7\right.$ to $8 \%$ ) is

14 between -5.1 and $-0.5 \%$ (estimate made using the calcite- $\mathrm{H}_{2} \mathrm{O}$ and ilmenite- $\mathrm{H}_{2} \mathrm{O}$

15 fractionation factors of Zheng, 1999 and 1991, respectively).

\section{Discussion}

18 9.1. Architecture of the URAPC

Contrary to most alkaline complexes worldwide, the Upper Ruvubu Alkaline Plutonic

20 Complex has an elliptic map contour. In Central Africa, 23 Neoproterozoic alkaline plutonic

21 massifs are distributed over a distance of $1700 \mathrm{~km}$ along the present-day Western Rift (i.e.

22 the western branch of the East African Rift; Tack et al., 1984). Their emplacement in

23 interpreted to reflect ascent of mantle-derived magmas along lithospheric weakness zones in

24 relation with the breakup of Rodinia (Burke et al., 2003; Hanson, 2003; Kampunzu et al., 
1 1997; Tack et al., 1984, 1996). This breakup is recorded at ca. 705 Ma at Matongo by the

2 LA-ICP-MS age of the zircon megacrysts (Midende et al., 2014), even though diachronous

3 reactivation in response to differential intraplate stress related to geodynamic processes

4 invoked by Li et al. (2008) and Eyles (2008) cannot be ruled out.

From structural evidence the URAPC was emplaced syntectonically, with NW-SE

6 oriented stretching parallel to the long axis of the elliptic shape - consistent with the NW-SE

7 trending regional foliation - and NE-SW oriented shortening. Numerous zones of high strain

8 where foliation is vertical have been observed in the field, essentially in the outer saturated

9 unit, but also in the inner unit. These zones can be interpreted as shear zones (Fig. 9). On the

10 horizontal plane, their kinematics indicates either dextral or sinistral movement (Fig. 9). The

11 largest shear zones occur near the centre of the Complex and display dextral kinematics,

12 indicative of shortening in the NE-SW direction. Even if the angle between dextral and

13 sinistral shear zones is relatively low, it is possible that they represent conjugated shear

14 zones. Alternatively, they could represent deformed zones accommodating ballooning of the

15 pluton in a pure shear regime. The schematic cross-section drawn in Figure 9B highlights the

16 vertical displacement associated with the shear zones. This is especially visible for the shear

17 zones limiting the roof pendant of metasediments close to the Matongo carbonatite. This zone

18 thus appears as a graben located near the roof of the Complex. In addition, both contact

19 metamorphism and deformation were synchronous (see section 4), which is a strong

20 argument in favour of a syntectonic emplacement of the URAPC.

21 Magmatic dykes in the north-west region are globally oriented $\mathrm{N} 30^{\circ}-\mathrm{N} 50^{\circ}$, as is the

22 large quartz vein, of magmato-hydrothermal affinity that crops out in the south-east region,

23 near Buraniro. Both structures are indicative of a NW-SE oriented stretching, consistent with

24 the NE-SW shortening direction deduced above. The fan-like pattern of the internal foliation 
1 observed in one of these dykes (Fig. 2C) also pleads for emplacement under a regime of

2 regional deformation.

3 The Matongo carbonatite does not outcrop. Nevertheless, some core samples

4 described in this study show a well-defined foliation of probable mylonitic origin developed

5 at magmatic temperatures. Indeed, the foliation is marked notably by the alignment of apatite

6 grains, some of them being fractured in a carbonated well-recrystallized matrix. We thus

7 propose that the elongated cartographic appearance of the carbonatite is due to its

8 emplacement along a sub-vertical shear zone. As a consequence, if most of the deformation

9 affected the outer unit of the URAPC, the latest stages of carbonatitic magmatism were still

10 syntectonic.

11 The shear zones may have acted as a preferential pathway for the carbonatitic magma

12 ascent. This also is also probably the case for the associated fluids, either coming from the

13 source mantle (as depicted by Nadeau et al., 2014) or from the surface, large permeabilities

14 being maintained in zones of deformation (e.g. Gapais et al., 2014). The fluid-rock

15 interactions observed in the field (see section 5.1) point to a long-lived hydrothermal system

16 initiated during magma emplacement and which survived magmatic activity. The geometry of

17 this system is controlled by the shear zones, which allowed fluids to circulate several

18 kilometres apart from the Matongo carbonatite body. Consequences of element mobility thus

19 occur at a large scale.

21 9.2. Origin of the carbonatitic dykes and their relationships with the Matongo carbonatite

The carbonatitic dykes of the URAPC show albitized material invaded by carbonates,

23 with fenitized margins at the contact with the deformed host rocks. This type of carbonatite,

24 displaying magmatic injection associated with brecciation and fenitization, occurs worldwide 
1 (e.g. Mountain Pass; Castor, 2008). It is particularly abundant in Central and Southern Africa

2 (e.g. carbonatitic system in the Itete and Mbeya Range area, Tanzania; Brown, 1964; in

3 Kirumba, DRC; Denayer, 1966; and at Swartbooisdrift, Namibia; Drüppel et al., 2005).

In the URAPC, the invasion of albitized clasts by carbonates suggests that brecciation

5 and fenitization slightly predate carbonatite injection (as testified by the magmatic $\mathrm{C}$ and $\mathrm{O}$

6 isotopic signature obtained on several invading carbonates from the carbonatitic

7 breccias/dykes). The early character of fenitization/albitization and brecciation is commonly

8 observed in carbonatitic breccias (e.g. at Mbeya Range, in Tanzania; Brown, 1964; in

9 Tundulu, Malawi; Ngwenya, 1994; and in Mountain Pass, U.S.A.; Castor, 2008).

10 Since the carbonatitic dykes of the URAPC were emplaced in an alkaline silicate

11 complex that also comprises a carbonatite body (Matongo), it is reasonable to consider that

12 both types of magmatic carbonates are related to each other, although significant differences

13 exist between them. The Matongo carbonatite body presents a typical suite from sövite to

14 ferrocarbonatite (Midende et al., 2014), while the carbonatitic dykes are merely characterized

15 by ferrocarbonatite and late calcite. In addition, the two carbonatite occurrences differ in

16 terms of fenitization : (1) a typical K-rich assemblage, comprising K-feldspar and biotite,

17 developed around the carbonatite body in the quartz syenite (Midende et al., 2014). Laterally,

18 this zone evolves, without clear continuity because of the lack of field evidence, towards (2)

19 an area where the carbonatite dykes are associated with Na-fenitisation (albitization). The

20 latter is less developed in the wall-rock than in the xenoliths of the carbonatitic matrix. The

21 presence of a K- and Na- zonation in the metasomatic aureole around carbonatites can be

22 explained by two distinct mechanisms (Le Bas, 1989): (1) the expulsion of different pulses of

23 alkali-rich fluids from the parental carbonatite magma at different depths or (2) the variable

$24 \mathrm{Na}: \mathrm{K}$ ratio of the parental carbonatite, from which the fluids are expelled. On the other hand,

25 the different $\mathrm{Na}: \mathrm{K}$ ratios of the different fluid pulses could derive from variation in pressure 
1 at which immiscible melts separate or from the evolution of a K-rich carbonatite magma from

2 an original primary Na-rich carbonatitic magma (Le Bas, 1989). Moreover, since the minerals

3 formed during the fenitization process are directly related to the wall-rock minerals (e.g.

4 albite is thought to be the result of the transformation of plagioclase, K-feldspar and

5 nepheline in a feldspathoidal syenite; Drüppel et al., 2005), an additional control of the wall-

6 rocks geochemistry cannot be ruled out. Consistently, the Matongo carbonatite body

7 predominantly intrudes quartz syenites $\left(\sim 5.3 \mathrm{wt} \% \quad \mathrm{~K}_{2} \mathrm{O}, \sim 4.6 \mathrm{wt} \% \mathrm{Na}_{2} \mathrm{O}\right)$, while the

8 carbonatitic dykes are mainly intruding feldspathoidal syenites, which are significantly richer 9 in $\mathrm{Na}\left(\sim 5.1 \mathrm{wt} \% \mathrm{~K}_{2} \mathrm{O}, \sim 8.3 \mathrm{wt} \% \mathrm{Na}_{2} \mathrm{O}\right)$.

Another notable fact is that the lateral extension of the K-fenitization affecting the

11 quartz syenites is quite large compared to the relative small volume of carbonatite in the

12 URAPC (Fig. 1A). This could be the witness of a larger carbonatitic system at-depth, as

13 proposed for the Copperhead albitite in Australia (Rugless and Pirajno, 1996) and at Mbeya

14 Range (Brown, 1964). In that scheme, (1) the Matongo carbonatite body would represent an intermediate-depth intrusion, with typical high-level K-fenitization, which evolved from a deeper Na-rich carbonatitic magma by the fractional crystallization, and (2) the carbonatitic

17 dykes could be the result of the injection of residual magmatic solutions from this body, 18 releasing Na-rich fluids and inducing Na-fenitization.

9.3. Pervasive alteration of the Matongo carbonatite

Most samples from the Matongo carbonatite body (sövites, ferrocarbonatites and

22 fenites) as well as many carbonatitic dykes show oxygen and carbon isotope compositions

23 that are typical of primary, magmatic, carbonatites (Taylor et al., 1967; Fig. 8A): the $\delta^{18} \mathrm{O}$

24 values are between 7.2 and $8.5 \%$ (vs. SMOW), the $\delta^{13} \mathrm{C}$ values are between -4.7 and $-5.4 \%$ 
1 (vs. PDB). Several carbonatitic dykes (RG 144739, RG 144742, RG 144748) also have a

2 signature $\left(7.9<\delta^{18} \mathrm{O}<9.75 \%\right.$ and $-5.60<\delta^{13} \mathrm{C}<-5.52 \%$ o $)$ close to the magmatic one; the

3 slightly higher $\delta^{18} \mathrm{O}$ values might be the sign of crystallization at a somewhat lower 4 temperature.

5 However, some sövites, ferrocarbonatites and fenites show evidence of secondary

6 alteration due to interactions with fluids, as shown by their shift to higher $\delta^{18} \mathrm{O}$ values (trend

71 in Fig. 8A). This shift is also highlighted in the RG 144751 and RG 144752 carbonatitic

8 dykes s. As a whole, the range of $\delta^{18} \mathrm{O}$ values from typical magmatic values at $7-8 \%$ to the

9 high values (between 20 and 22\%o) in the altered samples likely corresponds to varying

10 fluid/rock ratios during hydrothermal alteration. The fact that the $\delta^{13} \mathrm{C}$ values remain rather

11 constant (-4.7 to $-5.4 \%$ ) over the range of $\delta^{18} \mathrm{O}$ values indicates that the involved fluids were

$12 \mathrm{H}_{2} \mathrm{O}$-rich (i.e. $\mathrm{CO}_{2}$-poor, $\sim \mathrm{XCO}_{2}<0.05$ ). The most elevated $\delta^{18} \mathrm{O}$ values are those obtained

13 under infinite fluid/rock ratios, conditions under which the fluid imposes its isotopic

14 signature to the rock. Indeed, it has been shown that under open system conditions fluids

15 buffer rocks when the fluid/rock mass ratio is higher than 2 to 3 (e.g. Boulvais et al., 1998).

16 Interestingly, the samples with the highest $\delta^{18} \mathrm{O}$ values - i.e. the coarse-grained sövite

17 (sövite I) and the "late" hydrothermal calcite (occurring as vein infillings; Midende et al.,

18 2014) - show the most disturbed REE patterns (Fig. 7A). In Figure 8B, the intra-REE

19 fractionation resulting from the interaction with fluids is expressed by the ratio

$20\left(\mathrm{La}_{\mathrm{N}} * \mathrm{Sm}_{\mathrm{N}}\right) /\left(\mathrm{Ce}_{\mathrm{N}} * \mathrm{Nd}_{\mathrm{N}}\right)$, proposed by Irber (1999) to quantify the so-called tetrad effect (Bau,

21 1996). The observed correlation indicates that the oxygen isotope shift and the REE

22 disturbance are likely related to the same fluid-rock interaction. Obviously, REE, if mobile,

23 are much less efficiently transported than ${ }^{18} \mathrm{O}$ in aqueous fluids, so that the first stages of

24 alteration (low fluid/rock ratios) are not accompanied by REE disturbance, contrarily to the

25 most altered stages. The final result on the REE budget is an interne leaching of REEs from 
1 the sövite I (as also observed on Fig. 8C), showing that carbonatites with uncommon REE

2 patterns are also depleted in REE. In terms of pattern shape, late hydrothermal calcite,

3 occurring as thin veins crosscutting the sövite I, shares common characteristics with the host

4 coarse-grained sövite I. This suggests that the metasomatic fluids that invaded the carbonatite

5 body to form the carbonate veins were able to mobilize and fractionate the REEs. At

6 hydrothermal conditions between 150 and $300^{\circ} \mathrm{C}$, one can estimate the origin of the fluid by

7 calculating its $\delta^{18} \mathrm{O}$ value in equilibrium with the most altered samples $\left(\delta^{18} \mathrm{O}=20\right.$ to $22 \%$ ),

8 provided that the fluid:rock ratio was high enough so that the invading fluid kept its original

9 signature. Using the calcite- $\mathrm{H}_{2} \mathrm{O}$ fractionation factor of Zheng (1999), one obtains a wide

10 range of $\delta^{18} \mathrm{O}$ values for the hydrothermal aqueous fluid between 7 and $16 \%$. These values

11 point to a metamorphic fluid or, more generally, to fluids equilibrated with the surrounding

12 continental crust. More specifically, the high $\delta^{13} \mathrm{C}$ values of the most altered rocks $\left(\delta^{13} \mathrm{C}=-\right.$

134.7 to $0.2 \%$ o $)$ suggest the involvement of marine-derived carbon $\left(\delta^{13} \mathrm{C}\right.$ close to zero $)$, likely

14 incorporated in the hydrothermal fluid through its interaction with carbonated lithologies

15 during its migration in the country rocks around the URAPC. The Mesoproterozoic

16 metasedimentary rocks (Akanyaru Supergroup), in which the URAPC emplaced, is made up

17 of phyllites, graphitic schists, metaquartzites, interbedded metavolcanics and dolomite lenses

18 (Tack et al., 1984, Fernandez et al., 2012). This bedrock constitutes a possible source for

19 metamorphic fluids and interactions with Proterozoic carbonates $\left(\delta^{13} \mathrm{C}_{\mathrm{PDB}}\right.$ Proterozoic marine

20 carbonates: -2 to $+10 \%$; Bell and Simonetti, 2010). The comparable shift in terms of Sr isotope

21 composition (Fig. 8D) (Demaiffe, 2008; see the Supplementary material) could also reflect

22 this interaction. Indeed, most of the carbonatites (from the Matongo intrusion and the

23 carbonatitic dykes) display ${ }^{87} \mathrm{Sr} /{ }^{86} \mathrm{Sr}$ ratios comprised between 0.7028 and 0.7064 , while the

24 Sr isotopic ratios of the altered sövite I and "late" hydrothermal calcite are significantly

25 higher, ranging from 0.7128 to 0.7142 . 
1 Compared to this first alteration trend (trend 1 on Fig. 8A), the calcite veins occurring

2 in the Matongo carbonatite and host carbonatites sampled in the drill cores MAT1-5 display a

3 second trend (trend 2), which is characterized by an increase in both $\delta^{18} \mathrm{O}$ and $\delta^{13} \mathrm{C}$ values

4 (for $\delta^{18} \mathrm{O}$ values above $16.3 \%$, Fig. 8A). This suggests that the carbonatites were affected by

5 two alteration events recorded by the two trends $(1$ and 2$)$ in the $\delta^{13} \mathrm{C}-\delta^{18} \mathrm{O}$ diagram.

6 Calcite - that materializes this second alteration event in the drill cores - is

7 characterized by strong variations in terms of REE distribution. Such variations are observed

8 within a same drill core, suggesting that this alteration induced element (REE) mobilization

9 and redistribution, at least at a small scale.

11 9.4. General implications for fluid circulations and potential mineralizations in the URAPC

12 This study highlights the intimate association of deformation, magmatic emplacement

13 and hydrothermal activity in the URAPC. These processes have induced element

14 mobilization and reconcentration at the scale of the massif, thanks notably to the large extent

15 of shear zones. Element mobility is recorded for instance by the HFSE-rich megacrysts at

16 Inamvumvu and the REE mineral occurrences in the carbonatitic dykes.

17 The $\mathrm{O}$ isotope signatures of the zircon and ilmenite megacrysts from Inamvumvu 18 suggest a high temperature magmato-hydrothermal origin in equilibrium with the carbonatitic 19 reservoir. High-temperature processes are also responsible for REE concentration in the 20 carbonatitic dykes. Indeed, monazite is cogenetic with the early calcite (calcite 1), which has 21 a magmatic signature $\left(\delta^{18} \mathrm{O}=9.75 \%\right.$ and $\delta^{13} \mathrm{C}=-5.60 \%$ in sample $\left.\mathrm{RG} 144739\right)$. This 22 suggests that primary monazite has a late magmatic origin. Evidence of primary monazite in 23 carbonatites has been encountered - amongst others - at Kangankunde Hill (Malawi; Deans, 24 1966), at Mountain Pass (USA; Castor, 2008), and at Montviel (Canada; Nadeau et al., 25 2015).. 
1

$2\left(\delta^{18} \mathrm{O}=12.5 \%\right)$ is recorded by sample RG 144752, which contains ancylite-(Ce) coeval with

3 the predominant calcite 2 (second generation of calcite), suggesting circulation of "late"

4 hydrothermal fluids. The $\delta^{18} \mathrm{O}$ values measured on carbonatitic dykes were obtained on

5 "whole rock samples", and thus correspond to a mixture between several generations of

6 carbonates, some with low $\delta^{18} \mathrm{O}$ values, some with high $\delta^{18} \mathrm{O}$ values, possibly as high as the

7 value reached by the altered facies of the Matongo carbonatite $\left(\delta^{18} \mathrm{O}=20\right.$ to $\left.22 \%\right)$. It is

8 therefore possible that the REEs gained in the carbonatitic dykes could be due to the leaching

9 of the sövite I facies of the Matongo intrusion. Alternatively, the REE-carbonate of the

10 carbonatitic dykes could originate from evolved fluids directly derived from the carbonatite

11 magma and enriched in LREE, Sr (and F). A contribution from both sources cannot be ruled 12 out.

In addition, it is worth mentioning that the mineralization - HFSE and REE - seems

14 to be spatially associated with the different fenitization types. Indeed, (1) in the vicinity of the Matongo carbonatite body, where most of the late-magmatic HFSE mineralization occurs of magmatic and metasomatic/hydrothermal fluids to near-surface levels into the same conduits. Examples of carbonatitic systems showing spatial relationship between Na-fenites, (ferro)carbonatitic dykes and REE mineral occurrences include : (1) the Mesoproterozoic

23 Swartbooisdrift alkaline complex (Namibia), in which the Na-fenites are restricted to

24 ferrocarbonatitic dykes/breccias that comprise a REE-Sr mineralization (Drüppel et al.,

25 2005); (2) the Neoproterozoic alkaline complex of Kirumba (DRCongo), in which ankerite 
1 dykes invade fractured and albitized country rocks (Denayer, 1966), albite being frequently

2 associated with REE-minerals (Denayer, 1959). In addition to the fenitization, the

3 hydrothermal activity and associated mobility of elements are preferentially located in large

4 ductile shear-zones, which have been active during magma emplacement and cooling at sub-

5 solidus temperatures. Additional structural mapping of the URAPC is needed to obtain a 3D

6 geometry of the shear zones array and associated metallogenic system of the URAPC.

\section{Conclusion}

The large Neoproterozoic Upper Ruvubu Alkaline Plutonic Complex (URAPC),

10 located in Burundi along the western branch of the East African Rift, hosts carbonatites (as

11 intrusive body and dykes) and REE and HFSE mineral occurrences.

12 Syntectonic emplacement of the URAPC is revealed by its elliptic map contour. The

13 deformation was accommodated by large shear zones, one of them controlling the

14 emplacement of the Matongo carbonatite body. The shear zones array controlled the

15 geometry of the hydrothermal system associated with magmatic emplacement.

16 The $\mathrm{C}$ and $\mathrm{O}$ isotope compositions of the Matongo carbonatite body, of the zircon and

17 ilmenite megacrysts and of the carbonatitic dykes highlight the involvement of (1) late

18 magmatic-(carbonatitic) fluids in the formation of HFSE mineralizations and monazite, (2)

19 hydrothermal fluids (mostly metamorphic or - more generally - equilibrated with the

20 surrounding continental crust, with a contribution of the late-magmatic fluids) in the

21 deposition of ancylite-(Ce), and (3) late metamorphic fluids derived from the country rocks.

22 All these fluids induced - at least partly - the alteration and leaching of the REEs from the

23 primary carbonatite facies (sövite I) and their transport to form REE mineral occurrences, 
1 likely in the carbonatitic dykes. A contribution of REE from at deep-seated «parental»

2 carbonatitic magma is likely.

This study emphasizes the relationships between alkaline magmatism, carbonatite,

4 fluid circulations and REE-HFSE mineral occurrences at the scale of the URAPC. It also

5 indicates that these relationships are intimately associated with the regional deformation and

6 tectonic setting during the Neoproterozoic, seemingly related - at a much larger scale - to the

7 Rodinia breakup. Thus, insights from the URAPC give new keys to understand the geometric,

8 magmatic and metallogenic characteristics of other alkaline plutonic massifs, amongst others,

9 those distributed along the present-day western branch of the East-African Rift.

\section{Acknowledgments}

This study is part of the GECO project (Belgian Federal Public Service for Foreign

13 Affairs). Field work has been partly funded by the program of the Belgian development

14 agency, BTC, dedicated to the digitizing of the Burundi geological map. The author would

15 like to warmly thank the MRAC for providing the study samples. Luc André and Laurence

16 Monin are also thanked for their role in providing LA-ICP-MS analyses. The authors are also

17 grateful to Randall Parrish, editor, and Olivier Nadeau and Olivier Vanderhaeghe, reviewers,

18 for the helpful remarks on the manuscript. These comments have contributed to significantly

19 improve the quality of this paper.

\section{References}

Andersson, M., Malehmir, A., Troll, V. R., Dehghannejad, M., Juhlin, C., Ask, M., 2013. Carbonatite

23 ring-complexes explained by caldera-style volcanism. Nature Scientific reports 3, 1-9. 
Bau, M., 1996. Controls on the fractionation of isovalent trace elements in magmatic and aqueous

2 systems: Evidence from $\mathrm{Y} / \mathrm{Ho}, \mathrm{Zr} / \mathrm{Hf}$, and lanthanide tetrad effect. Contribution to Mineralogy and Petrology

$3123,323-333$.

4 Bell, K., Simonetti, A., 2010. Source of parental melts to carbonatites-critical isotopic constraints.

5 Mineralogy and Petrology 98, 77-89.

Bonin, B., Giret, A., 1985. Contrasting roles of rock-forming minerals in alkaline ring complexes.

Journal of African Earth Sciences 3, 41-49.

8

$9 \mathrm{C}$ and $\mathrm{O}$ isotopic signatures in marbles subject to Pan-African granulite-facies metamorphism and U-Th 10 mineralization (Tranomaro, southeast Madagascar). Chemical Geology 150, 247-262.

Bowden, P., 1985. The geochemistry and mineralization of alkaline ring complexes in Africa (a review). Journal of African Earth Sciences 3, 17-39.

Brown, P.E., 1964. The Songwe scarp carbonatite and associated feldspathization in the Mbeya Range,

and carbonatites. Geology 31, 391-394

Castor, S.B., 2008. The Mountain Pass rare-earth carbonatite and associated ultrapotassic rocks,

California. Canadian Mineralogist 46, 779-806.

Chakhmouradian, A. R., 2006. High-field-strength elements in carbonatitic rocks: geochemistry, crystal chemistry and significance for constraining the sources of carbonatites. Chemical Geology 235, 138-160.

Chakhmouradian, A. R., Zaitsev, A. N., 2012. Rare earth mineralization in igneous rocks: sources and processes. Elements 8, 347-353. oxides and silicates for isotopic analysis. Geochimica et Cosmochimica Acta 27, 43-52. 
Demaiffe, D., 2008. Le magmatisme alcalin et carbonatitique: synthèse sur la province paléozoique de

2 Kola (Russie) et caractéristiques générales du massif protérozoique de Matongo (Burundi). Bulletin de Séances

3 de l'Académie royale des Sciences d'Outre-Mer 54, 171-196.

4 Denayer, M.E., 1959, Les syénites métasomatiques du massif de Kirumba : Mémoires de l'Académie

$5 \quad$ Royale des Sciences Coloniales, Classe des Sciences Techniques NS 9 (2), 234 p.

6 Denaeyer, M.E., 1966. Sur la présence d'une carbonatite ankéritique (rauhaugite) en bordure du 7 complexe alcalin de Kirumba (Kivu). Comptes Rendus de l'Académie des Sciences de Paris 263 (D), 9-12. DFID, 2002.Local phosphate resources for sustainable development in sub-Saharan Africa. Economic

9 Minerals and geochemical Baseline Programme. Report CR/02/121/N. British Geological Survey.

10 http://www.bgs.ac.uk/research/international/dfid-kar/CR02121N_col.pdf.

11 Drüppel, K., Hoefs, J., and Okrusch, M., 2005. Fenitizing processes induced by ferrocarbonatite 12 magmatism at Swartbooisdrif, NW Namibia. Journal of Petrology 46, 377-406.

Eyles, N., 2008. Glacio-epochs and the supercontinent cycle after $\sim 3.0 \mathrm{Ga}$ : Tectonic boundary

conditions for glaciation. Palaeogeography, Palaeoclimatology, Palaeoecology 258, 89-129.

Fernandez-Alonso, M., Cutten, H., De Waele, B., Tack, L., Tahon, A., Baudet, D., and Barritt, S.D.,

2012. The Mesoproterozoic Karagwe-Ankole Belt (formerly the NE Kibara Belt): The result of prolonged

17 extensional intracratonic basin development punctuated by two short-lived far-field compressional events. Precambrian Research 216, 63-86.

Fransolet, A.M., and Tack, L, 1992. Les zircons de Matongo (Burundi) et leur signification. Annales de la Société géologique de Belgique 115, 113-118. deposits within ancient hot orogens. Tectonophysics 618, 102-106. 
Gieré, R., 1996. Formation of rare earth minerals in hydrothermal systems, in: Jones, A.P., Wall, F.,

2 Williams, C.T. (Eds.), Rare Earth minerals, The Mineralogical Series, 7. Chapman \& Hall, London, UK, pp. 3 $105-150$

Grey, I.E., Reid, A.F., 1975. The structure of pseudorutile and its role in the natural alteration of 5 ilmenite. American Mineralogist 60, 898-906.

Hanson, R.E., 2003. Proterozoic geochronology and tectonic evolution of southern Africa, in: Yoshida,

M. et al. (Eds.), Proterozoic East Gondwana: Supercontinent assembly and breakup. Geological Society, London, Special Publications, 206, pp. 427-463.

Irber,W., 1999. The lanthanide tetrad effect and its correlation with $\mathrm{K} / \mathrm{Rb}, \mathrm{Eu} / \mathrm{Eu} * \mathrm{Sr} / \mathrm{Eu}, \mathrm{Y} / \mathrm{Ho}$, and

$\mathrm{Zr} / \mathrm{Hf}$ of evolving peraluminous granite suites. Geochimica et Cosmochimica Acta 63, 489-508.

Kampunzu, A.B., Kramers, J., and Tembo, F., 1997. Neoproterozoic alkaline and carbonatite magmatism along the western rift in Central-Eastern Africa: Break-up of Rodinia supercontinent and reconstruction of Gondwana. Gondwana Research 1, 155-156.

Kempe, U., Götze, J., 2002. Cathodoluminecence (CL) behaviour and crystal chemistry of apatite from rare-metal deposits. Mineralogical Magazine 66,151-172.Kurtanjek, M.P., Tandy, B.C., 1989. The igneous phosphate deposits of Matongo-Bandaga, Burundi, in: Notholt, A.J.G., Sheldon, R.P., Davidson, D.F. (Eds.),

Phosphate deposits of the world. Vol. 2. Phosphate rock resources. Cambridge University Press, Cambridge, UK, pp. 262-266.

Le Bas, M.J., 1989. Diversification of carbonatite, in: Bell, K. (Ed.), Carbonatites: Genesis and

Evolution. London, Unwin Hyman, pp. 428-447.

Li, Z.X., Bogdanova, S.V., Collins, A.S., Davidson, A., De Waele, B., Ernst, R.E., Fitzsimons, I.C.W.,

Fuck, R.A., Gladkochub, D.P., Jacobs, J., Karlstrom, K.E., Lu, S., Natapov, L.M., Pease, V., Pisarevsky, S.A., 
Marks, M.A.W., Neukirchen, F., Venneman, T., Markl, G., 2009. Textural, chemical, and isotopic

2 effects of late-magmatic carbonatitic fluids in the carbonatite-syenite Tamazeght complex, High Atlas

3 Mountains, Morocco. Mineralogy and Petrology 97, 23-42.

4 Marshall, D.J., 1988. Cathodoluminescence of Geological Materials. Unwin Hyman, Boston. 146 p.

5 Midende, G. 1984. La carbonatite de Matongo (Burundi). Unpublished PhD thesis, Université Libre de 6 Bruxelles, Bruxelles, 288 p.

7 Midende, G., Boulvais, P., Tack, L., Melcher, F., Gerdes, A., Dewaele, S., Demaiffe, D., Decrée, S., 8 2014.Petrography, geochemistry and U-Pb zircon age of the Matongo carbonatite Massif (Burundi): implication 9 for the Neoproterozoic geodynamic evolution of Central Africa. Journal of African Earth Sciences 100, 656674.

Mitchell, R.H., 2014. Primary and secondary niobium mineral deposits associated with carbonatites.

Ore Geology Reviews 64, 626-641.

Nadeau, O., Stevenson, R., Jébrak, M., 2014. The Archean magmatic-hydrothermal system of Lac

Shortt (Au-REE), Abitibi, Canada: Insights from carbonate fingerprinting. Chemical Geology 387, 144-156.

Nadeau, O., Cayer, A., Pelletier, M., Stevenson, R., Jébrak, M., 2015. The Paleoproterozoic Montviel carbonatite-hosted REE-Nb deposit, Abitibi, Canada: Geology, mineralogy, geochemistry and genesis. Ore Geology Reviews 67, 314-335.

Ngwenya, B., 1994. Hydrothermal rare-earth mineralization in carbonatites of the Tundulu Complex, Malawi - Processes at the fluid-rock interface. Geochimica Cosmochimica Acta 58, 2061-2072.

Nkurikiye, L., 1989. Le kaolin au Burundi: Contribution à sa caractérisation, sa genèse et son utilisation. Unpublished M. Sc. Thesis, Burundi University.Notholt, A.J.G., 1999. Phosphate: a world monograph (A compilation of unfinished paper). British Geological Survey. 
Platt, R.G., 1996. Nepheline-syenite complexes - an overview, in: Mitchell, R.H. (Ed.), Undersaturated

2 alkaline rocks: Mineralogy, petrogenesis, and economic potential. Short Course Series 24, Mineralogical

3 Association of Canada, Winnipeg, pp. 63-100.

4 Pownceby, M.I., 2010. Alteration and associated impurity element enrichment in detrital ilmenites from 5 the Murray basin, southeast Australia: a product of multistage alteration. Australian Journal of Earth Sciences $6 \quad 57,243-258$.

Rugless, C.S., Pirajno, F., 1996. Geology and geochemistry of the Copperhead Albitite 'Carbonatite'

8 Complex, east Kimberley, Western Australia. Australian Journal of Earth Sciences 43, 311-322.

Simonetti, A., Bell, K., 1994. Isotopic and geochemical investigation of the Chilwa Island carbonatite

complex, Malawi: evidence for a depleted mantle source region, liquid immiscibility, and open-system behaviour. Journal of Petrology 35,1597-1621.

Spoetl, C., Vennemann, T. W., 2003. Continuous-flow isotope ratio mass spectrometric analysis of carbonate minerals. Rapid Communications in Mass Spectrometry 17, 1004-1006.

Stoch, L., Sikora, W., 1976. Transformation of micas in the process of kaolinitization of granites abnd gneisses. Clay and Clay Minerals 24, 156-162.

Stormer , J. C., Pierson, M. L., Tacker, R. C., 1993. Variation of F and Cl X-ray intensity due to anisotropic diffusion in apatite. American Mineralogist 78, 641-648.

Sun, S.S., 1982. Chemical composition and origin of the Earth's primitive mantle. Geochimica Cosmochimica Acta 46, 179-192.

Tack, L., De Paepe, P., Deutsch, S., Liégeois, J.P., 1984. The alkaline plutonic complex of the Upper

Ruvubu (Burundi): geology, age, isotopic geochemistry and implications for the regional geology of the Western rift, in: Klerkx, J., and Michot, J. (Eds.), African Geology: Tervuren, pp. 91-114.

Tack, L., Liégeois, J.P., André, L., Navez, J., 1995. The Upper Ruvubu alkaline plutonic complex (Burundi). Annual Report of the Royal Museum for Central Africa, Tervuren, p. 9.

Tack, L., Deblond, A., De Paepe, P., Duchesne, J.C., Liégeois, J.P., 1996. Proterozoic alignements of 
2 Alonso, M., 2010. The 1375 Ma "Kibaran event" in Central Africa: prominent emplacement of bimodal

3 magmatism under extensional regime. Precambrian Research 180, 63-84.

Taylor, H.P.Jr, Frechen, J., Degens, E.T., 1967. Oxygen and carbon isotope studies of carbonatites

5 from Laacher See district, West Germany and Alnø district, Sweden. Geochimica et Cosmochimica Acta 31, $6 \quad 407-430$.

Valley, J.W., 2003. Oxygen isotopes in zircon. Reviews in mineralogy and geochemistry 53, 343-

8 385.Wall, F., Mariano, A. N., 1996. Rare earth minerals in carbonatites: a discussion centred on the

9 Kangankunde Carbonatite, Malawi, in: Jones, A.P., Wall, F., Williams, C.T. (Eds.), Rare Earth minerals, The

Mineralogical Series, 7. Chapman \& Hall, London, UK, pp. 193-226.

Waychunas, G.A., 2002. Apatite luminescence. In: Kohn MJ, Rakovan J, Hughes JM (eds) Reviews in pp. 701-742.

Williams-Jones, A. E., Migdisov, A. A., Samson, I. M., 2012. Hydrothermal mobilisation of the rare earth elements-a tale of "ceria" and "yttria". Elements 8, 355-360.

Wyllie, P.J., Jones, A.P., Deng, J., 1996. Rare earth elements in carbonatite-rich melts from mantle to 


\section{Figure and Table captions}

3 Figure 1. (A) Geological sketch map of the studied area (modified and redrawn from Tack et al., 1984, and after Fernandez-Alonso et al., 2012), with an insert showing the alkaline complexes along the western branch of the East African Rift system (redrawn from Tack et al., 1984). (B) location of the showings/deposits, samples (RG 144739, RG 144752, GPS74) and boreholes (from S1 to S8, from ITS3 to ITS5) mentioned in the text (see also Table 8 in the Supplementary material for the correspondence between samples and drill cores).

9 Figure 2. Field pictures showing the intrusive contact between the Buraniro Granite (A) and the

Figure 3. Field pictures (A-E) and mineral occurrences $(F-H)$ showing the relationships between magmatism, deformation and hydrothermal fluid circulation within the URAPC. (A) Deformed quartz + hematite vein in the quartz syenite, (B) Slickenslide lineation on hematite in the shear plane of the quartz+hematite vein shown in figure A. (C) Carbonatitic venue emphasized by the presence of an albite vein in a fenitized feldspathoidal syenite. (D) Representative outcrop of a deformed and fenitized feldspathoidal syenite comprising a carbonatite vein. (E) Carbonatitic dykes with albitized clasts and the invading carbonatite (Carb) in the felspathoidal syenite (sample RG 144752). (F) Deformed felspathoidal syenite (the foliation is parallel to the pen) cross-cut by a dyke comprising feldpathoids and oxides. (G) Highly mylonitized quartz syenite. (H) Tension gashes filled with feldpathoid (sodalite in blue) in a mylonitized quartz syenite. (I-J): Euhedral zircon megacrysts originating from the 
Inamvumvu hill and set in a lateritic crust. (K) Euhedral ilmenite megacryst from the Inamvumvu hill.

3 Figure 4. Pictures of the Matongo drill cores, which are strongly invaded by calcite veins. The numbers and pink lines correspond to the micro-drill sampling for the stable isotope study.

5 Figure 5. Photomicrographs of the carbonatitic dykes (sample RG 144.752) in transmitted light (A), cathodoluminescence (D-E), and backscattered electron images (B-C, F-G). Abbreviations are as follows: Calc 1 for the first generation of Fe-Mn-rich calcite, Calc 2 for the second generation of calcite, Ilm for ilmenite, Fluorap for fluorapatite, Rut for rutile and Str for strontianite. (A) Muscovite vein in an albitized clast, partly slightly silicified (leading to cloudy albite). (B) Muscovite vein in an albitized clast. Ancylite-(Ce) replacing a muscovite lath in this vein. (C) Biotite aggregates within albitized clast; rims of biotite laths are transformed into a Ba-rich biotite and occur in association with euhedral zircon and ilmeniterutile intergrowths; monazite occurs as interstitial phase of biotite. (D) Assemblage comprising pink albite, biotite, dull luminescent calcite 1 and blue apatite in the matrix of the carbonatitic dykes; late calcite (orange in $\mathrm{Cl}$ ) and bright strontianite replace earlier calcite 1 (see text for further comments). (E) Blue-luminescing monazite. (F) Biotite, calcite 1 and fluorapatite invading an albitized clasts; insert shows ancylite-(Ce) associated with calcite 2 replacing albite. (G) Assemblage of biotite, late calcite 2 and strontianite in the matrix of the carbonatitic dykes. Monazite seems associated with biotite, while ancylite-(Ce) is interstitial to biotite laths.

Figure 6. Photomicrographs of the Matongo drill cores in transmitted light (A) and cathodoluminescence (B-C). Abbreviations are as follows: Felds for K-feldspar and Fluorap for fluorapatite. (A) Typical vein, where calcite is associated with fluorapatite and oxides in the MAT 1a drill core. (B) Vein comprising dolomite and fluorapatite within the host calciocarbonatite, which is associated with K-feldspar (MAT 3 drill core). (C) Alignment of fluorapatite parallel to the foliation (MAT 3 drill core). See text for further explanation. 
1 Figure 7. Chondrite-normalized REE abundance patterns of the minerals from the carbonatitic dykes (A-B), from the Matongo drill cores (C-E) and of the megacrysts from the Inamvumvu laterite and kaolin (F-G) (LA-ICP-MS analyses). (A) Fluorapatites and calcites from the carbonatitic dykes and comparison with whole-rock analyses of various facies of the Matongo carbonatite (sövite I, sövite II and late hydrothermal calcite; Midende et al., 2014). (B) REE-minerals monazite and ancylite-(Ce) - from the carbonatitic breccias. (C) Two calcite types from veins of the MAT 1 drill core. (D) Two calcite types from veins of the MAT 2 drill core. (E) Fluorapatites and calcite from veins of the MAT 3 drill core. Host calciocarbonatite analyses are given for comparison purposes. (F) Zircons megacrysts from the laterite and kaolin deposit. (G) Ilmenite megacrysts from the laterite and kaolin deposits. (Normalization values to the chondrites from Sun (1982) and McDonough (1990).

Figure 8. (A) $\delta^{13} \mathrm{C}$ versus $\delta^{18} \mathrm{O}$ isotopic diagram for the various facies of the Matongo carbonatite and for the carbonatitic dykes. The carbonatite box corresponds to the isotopic signature of the primary (=magmatic) carbonatites (Taylor et al., 1967). See the text for explanations about trends $1 \& 2$. (B) Correlation between the oxygen isotopic composition and the tetrad effect. Data relating the zircon and ilmenite megacrysts from the Inamvumvu hill are also plotted in this diagram. (C) Correlation between the oxygen isotopic composition and the sum of REE. (D) ${ }^{87} \mathrm{Sr} /{ }^{86} \mathrm{Sr}$ (initial recalculated ratios) versus $\delta^{18} \mathrm{O}$ isotopic diagram for several facies of the Matongo carbonatite and for the carbonatitic breccias.

Figure 9. Schematic structural map and cross-section of the URAPC highlighting the role of shear zones in controlling the geometry of the Complex. Some shear zones have been observed on the field (they are marked by an asterisk on the cross-section), some others have been inferred from the global geometry. 
1 - This study focuses on a Neoproterozoic syntectonic alkaline complex in Burundi

2 - Field observations evidence fluid-rock interactions in relation with deformation

3 - Petrographic and geochemical data testify for different fluid circulations

4 - HFSE and REE mobilizations/mineral occurrences are related to these circulations 5 


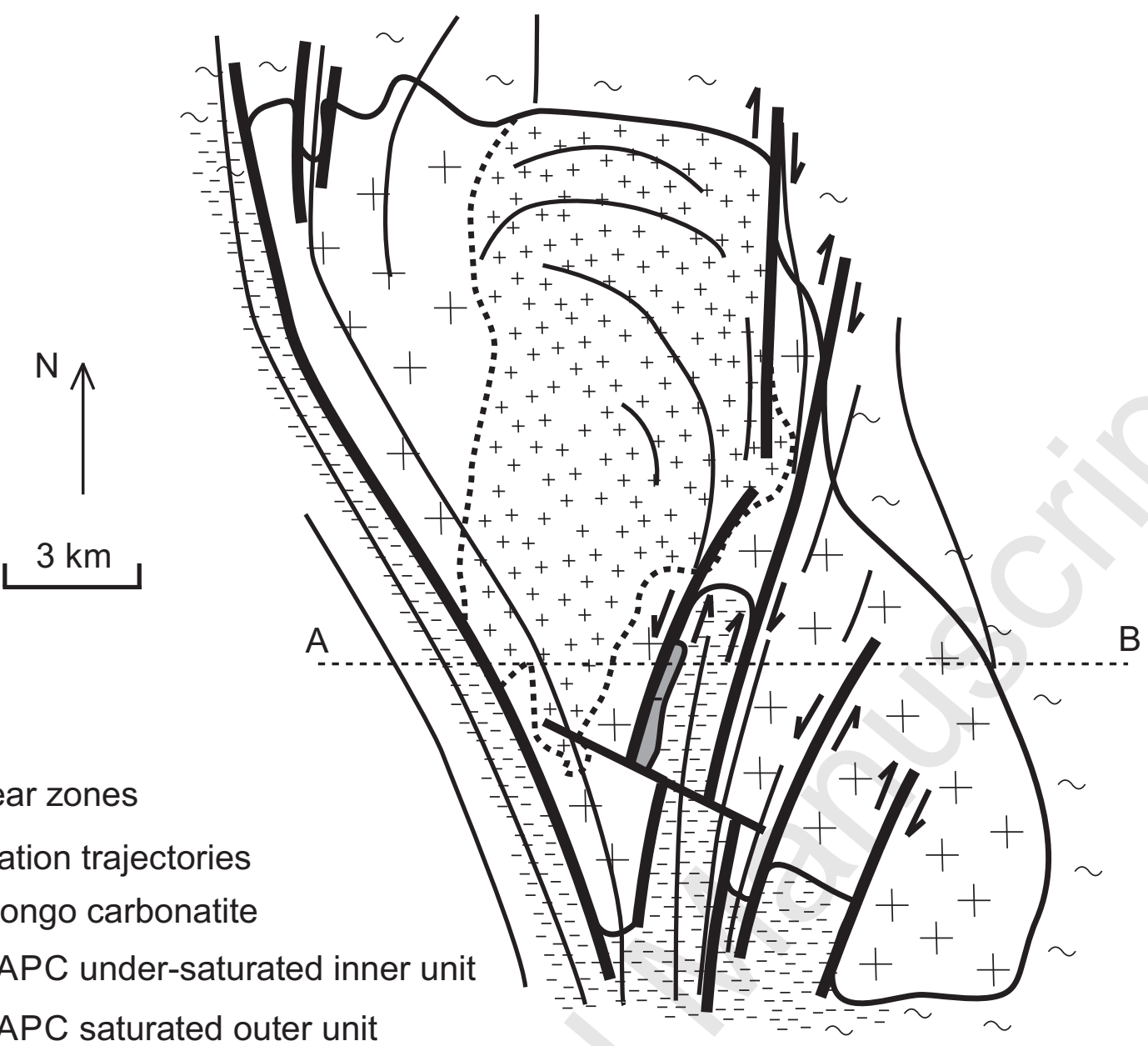

+ URAPC saturated outer unit

三立 Medium-grade metasediments

$\sim \sim$ High-grade gneisses and metapelites

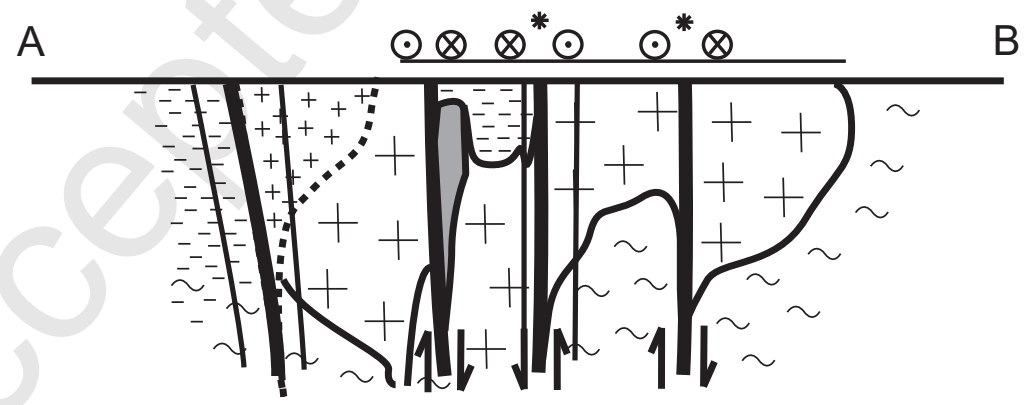



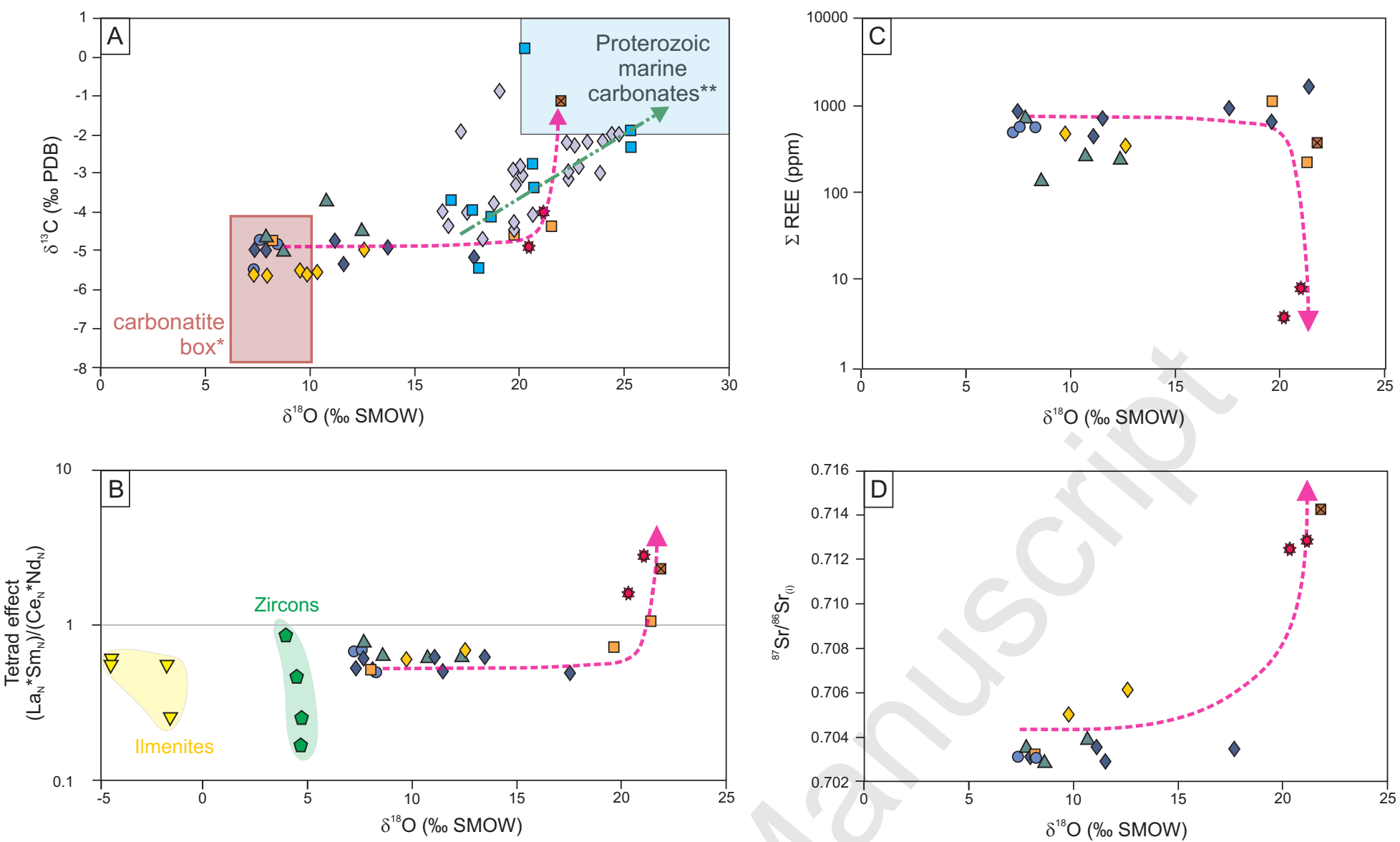

Matongo carbonatite Facies described by Midende et al. (2014)

MAT 1-5 drill cores (this study)

$\begin{array}{llll}\text { Coarse-grained sövite I } & \begin{array}{l}\text { Ferrocarbonatite } \\ \text { Fine-grained sövite II }\end{array} & \circ & \begin{array}{l}\text { "Late" hydrothermal } \\ \text { calcite }\end{array} \\ \begin{array}{l}\text { Sövite II with apatite } \\ \text { and pyroxene }\end{array} & \diamond & \begin{array}{l}\text { Fenite } \\ \text { and }\end{array}\end{array}$
and pyroxene

\section{Calciocarbonatite $\square$ \\ Calcite veins $\diamond$}

\section{Carbonatitic dykes $\diamond$}

Alteration trend 1

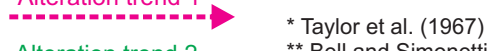

Alteration trend 2 

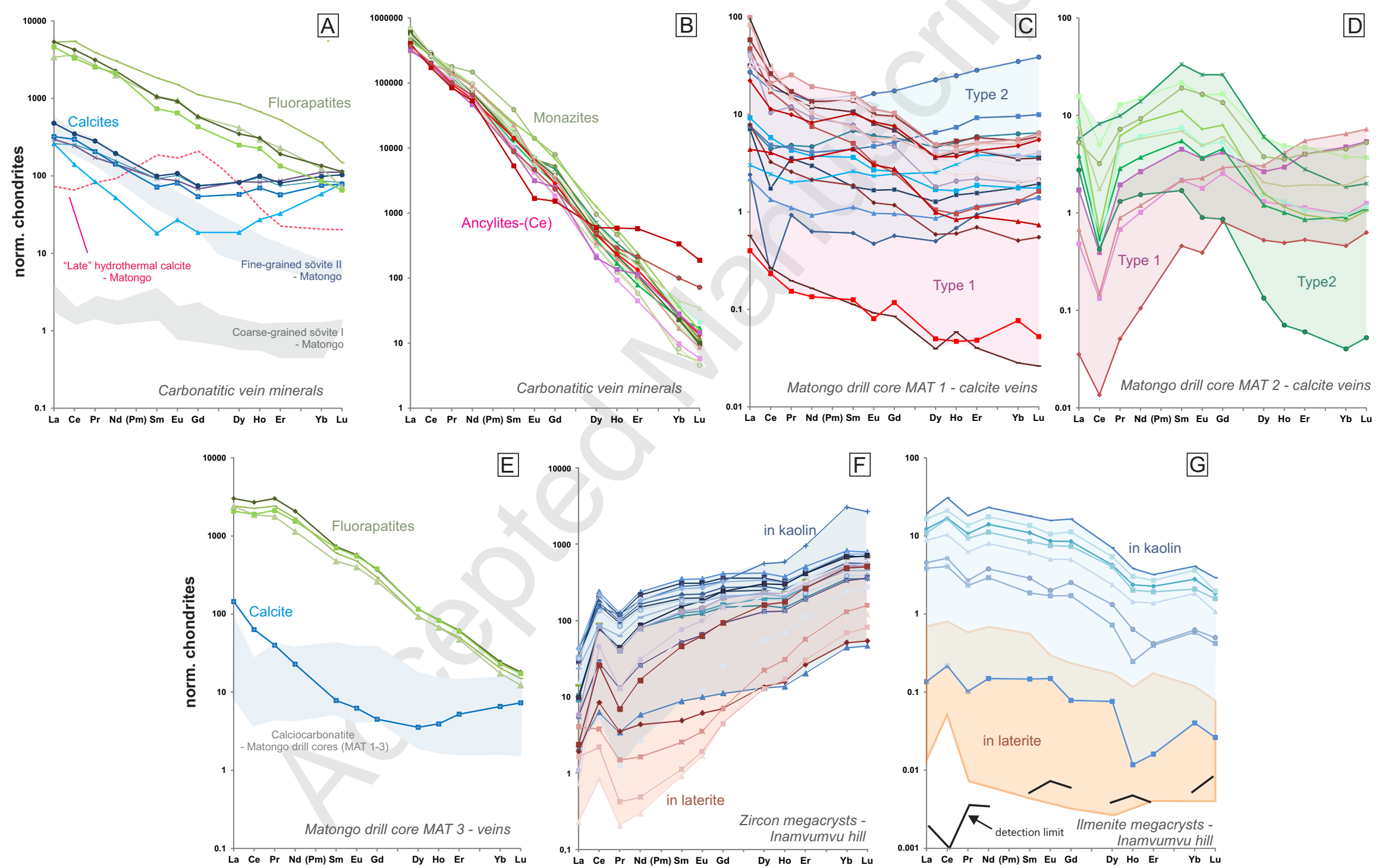


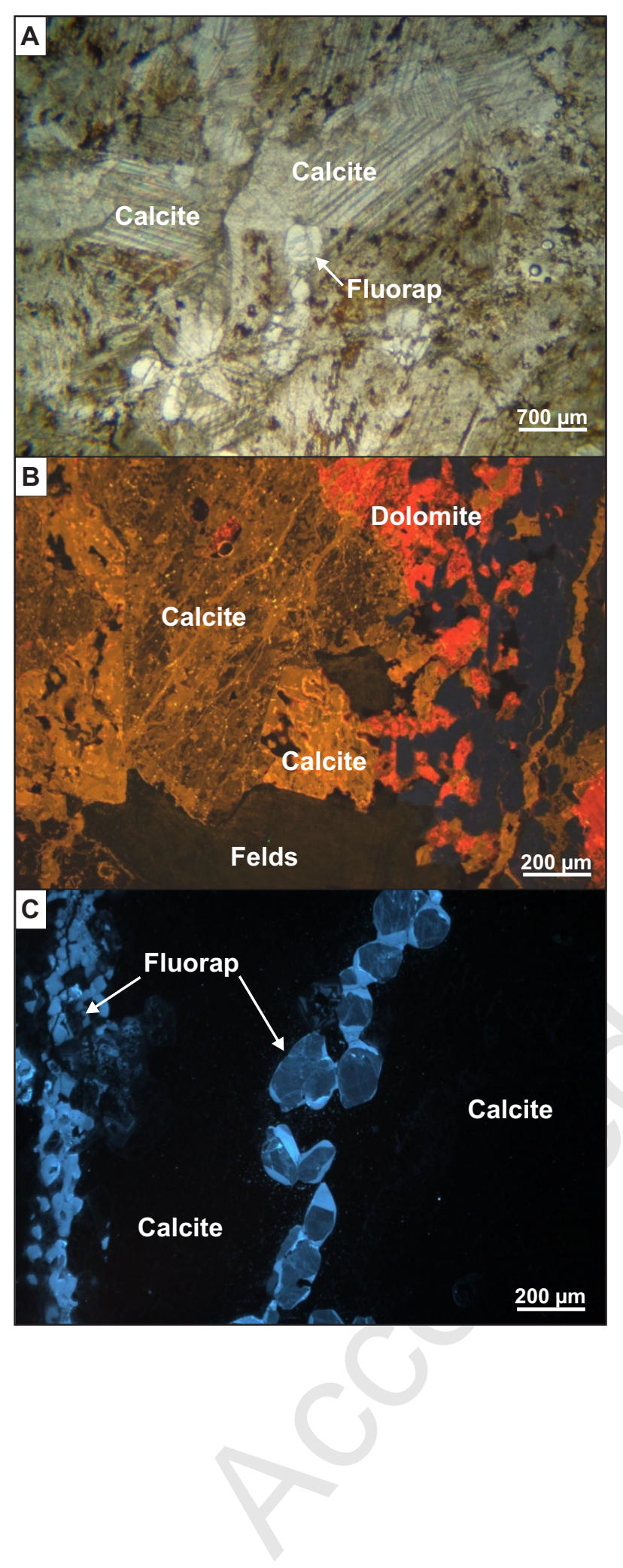




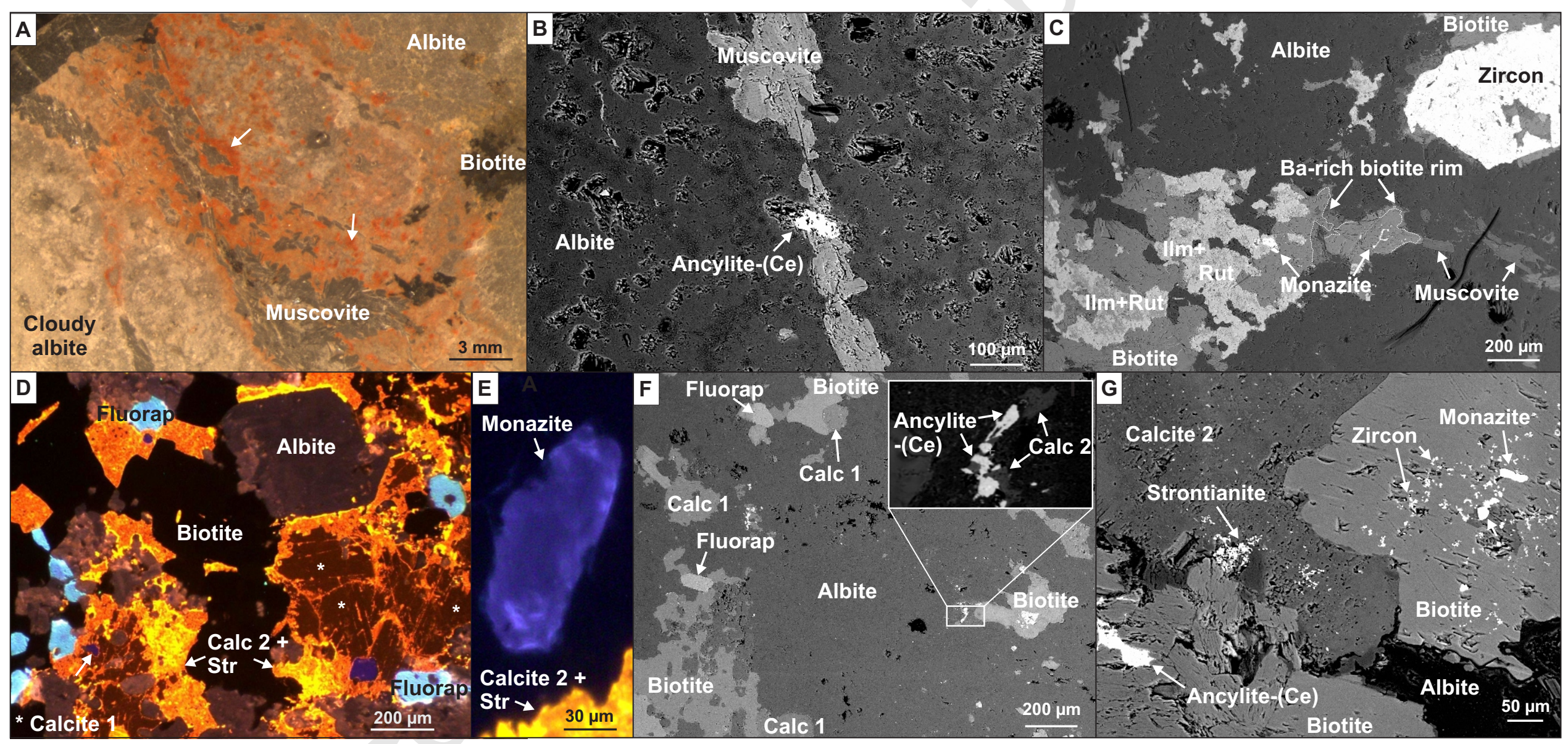




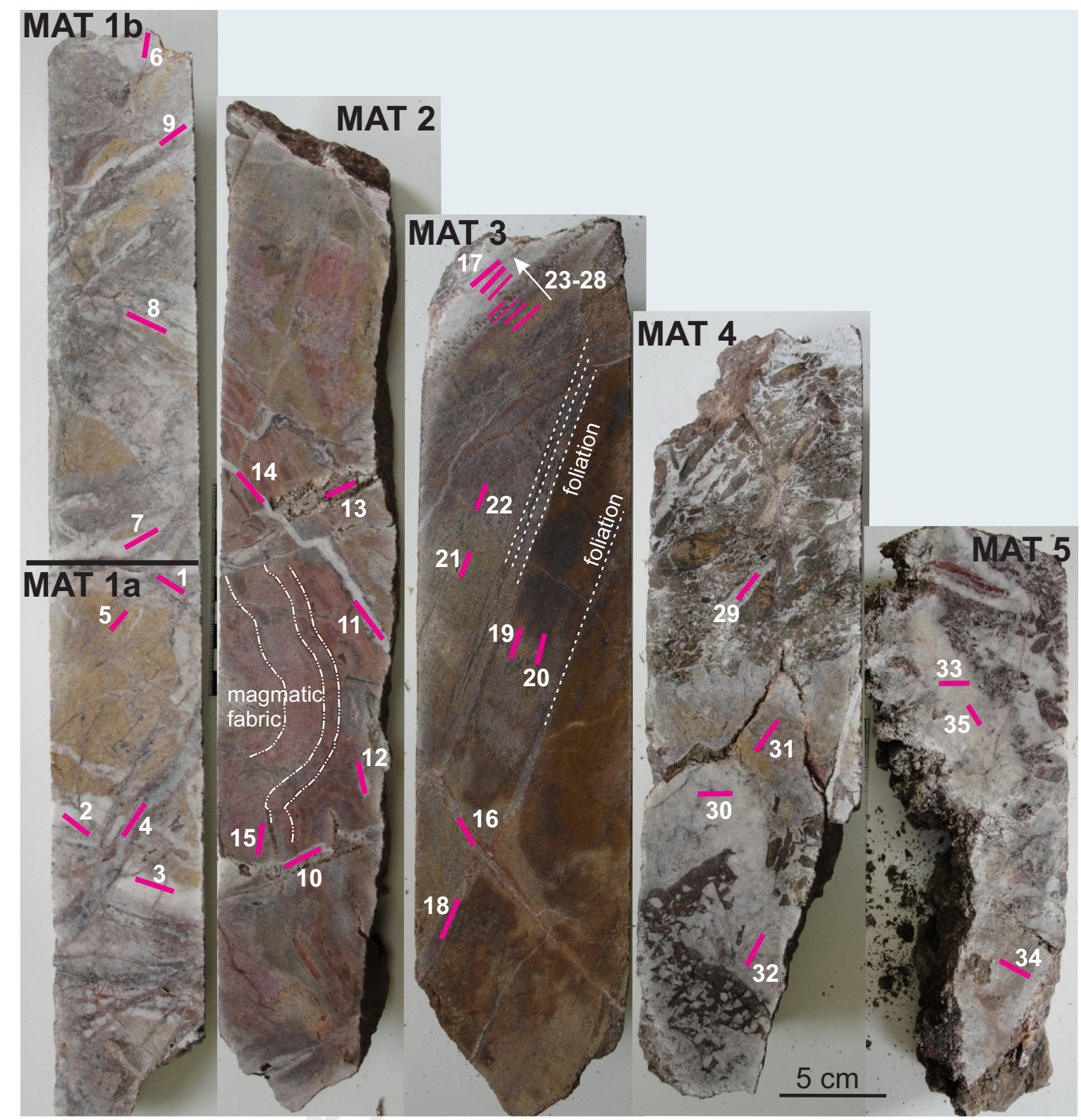


ACCEPTED MANUSCRIPT

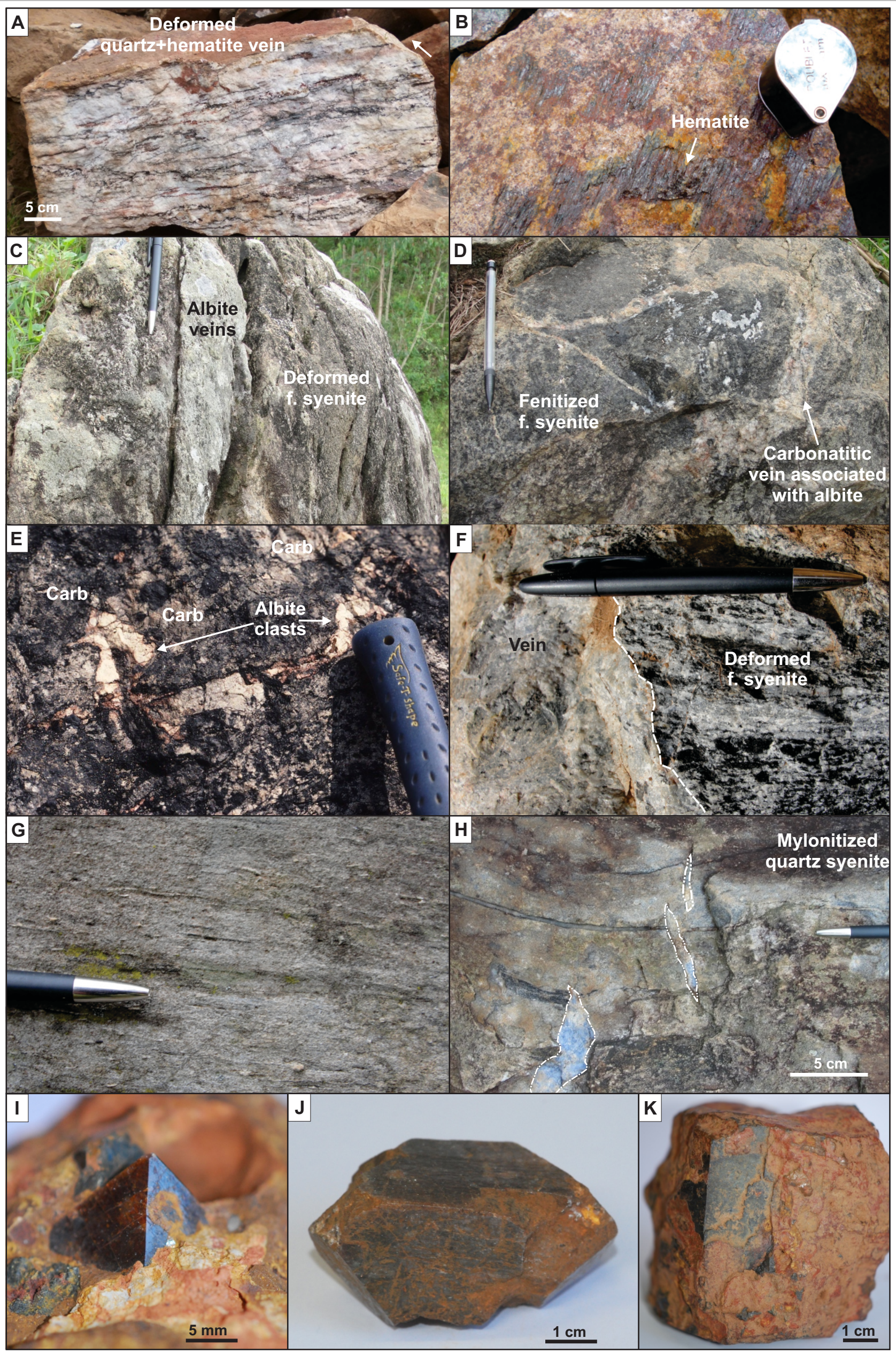


ACCEPTED MANUSCRIP'

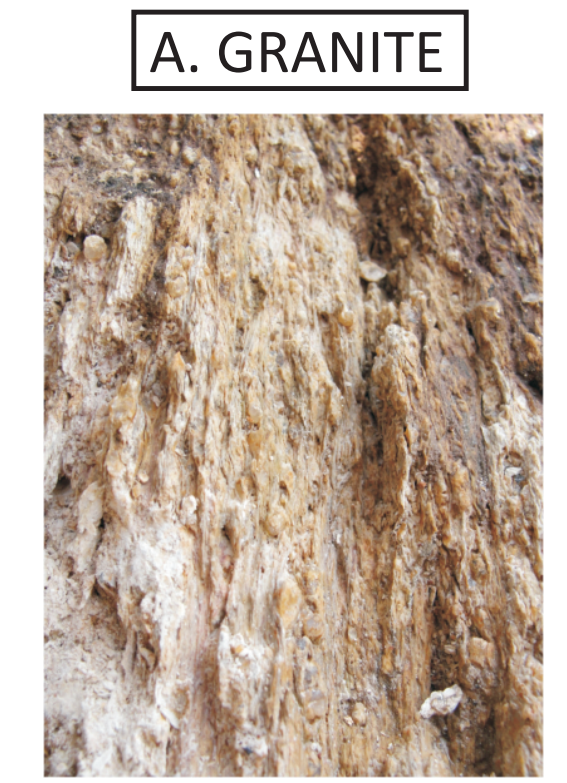

$1 \mathrm{~m}$

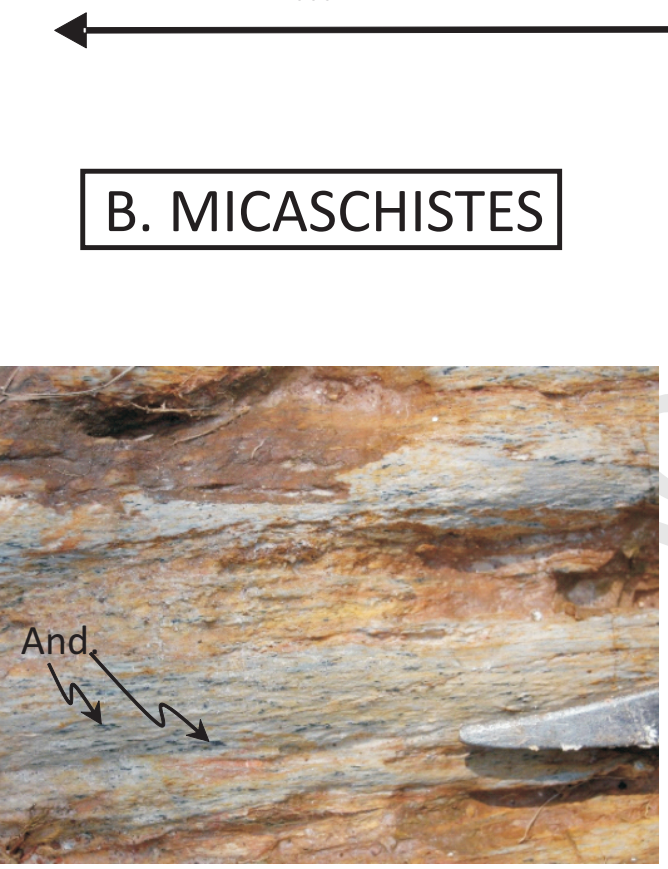

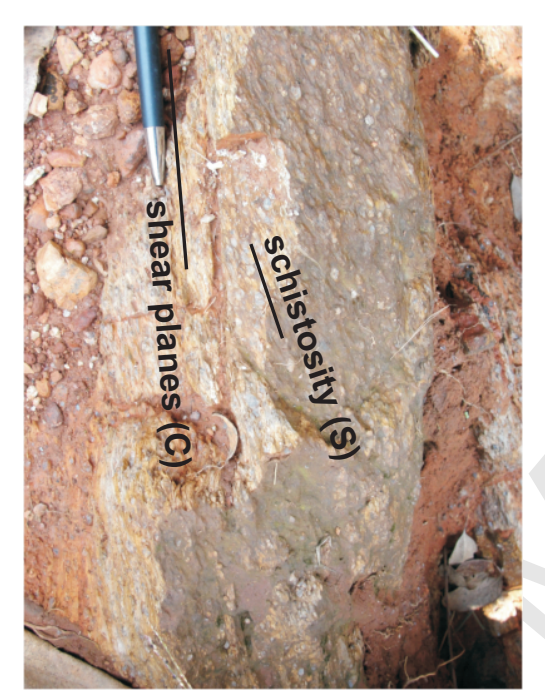

$20 \mathrm{~m}$

Toward the contact

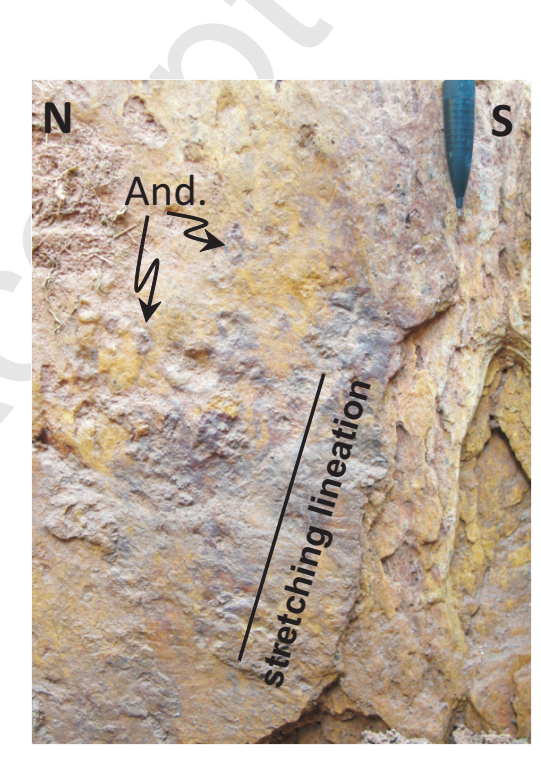

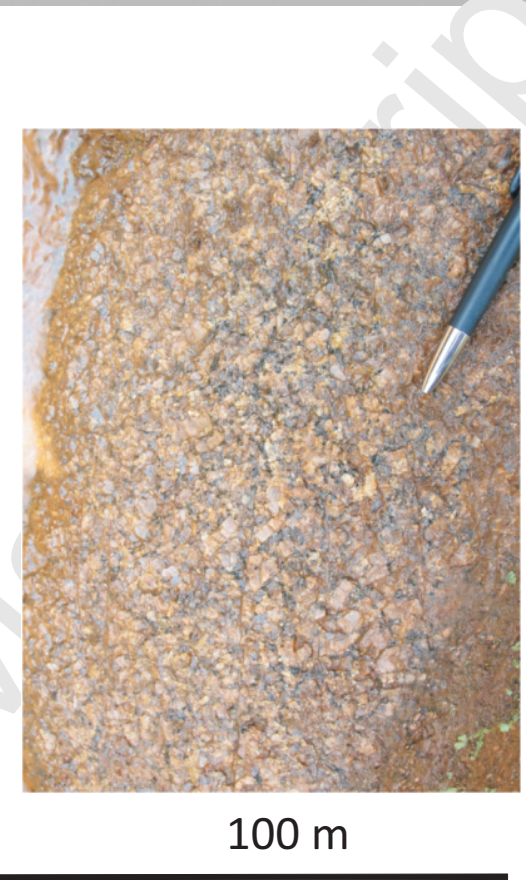

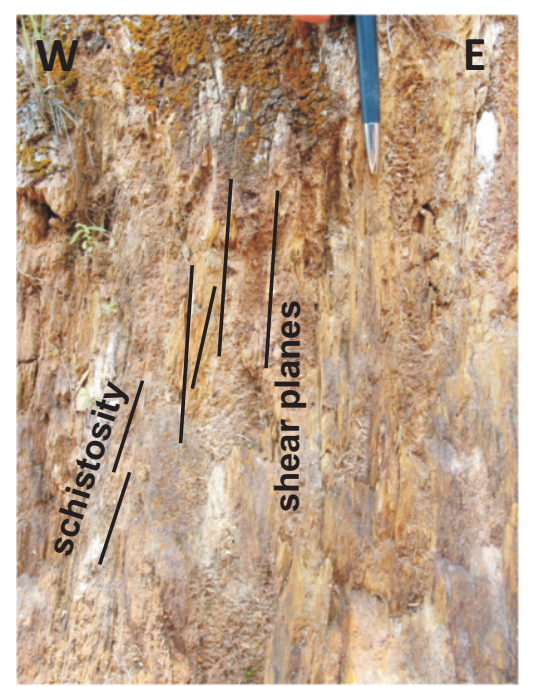

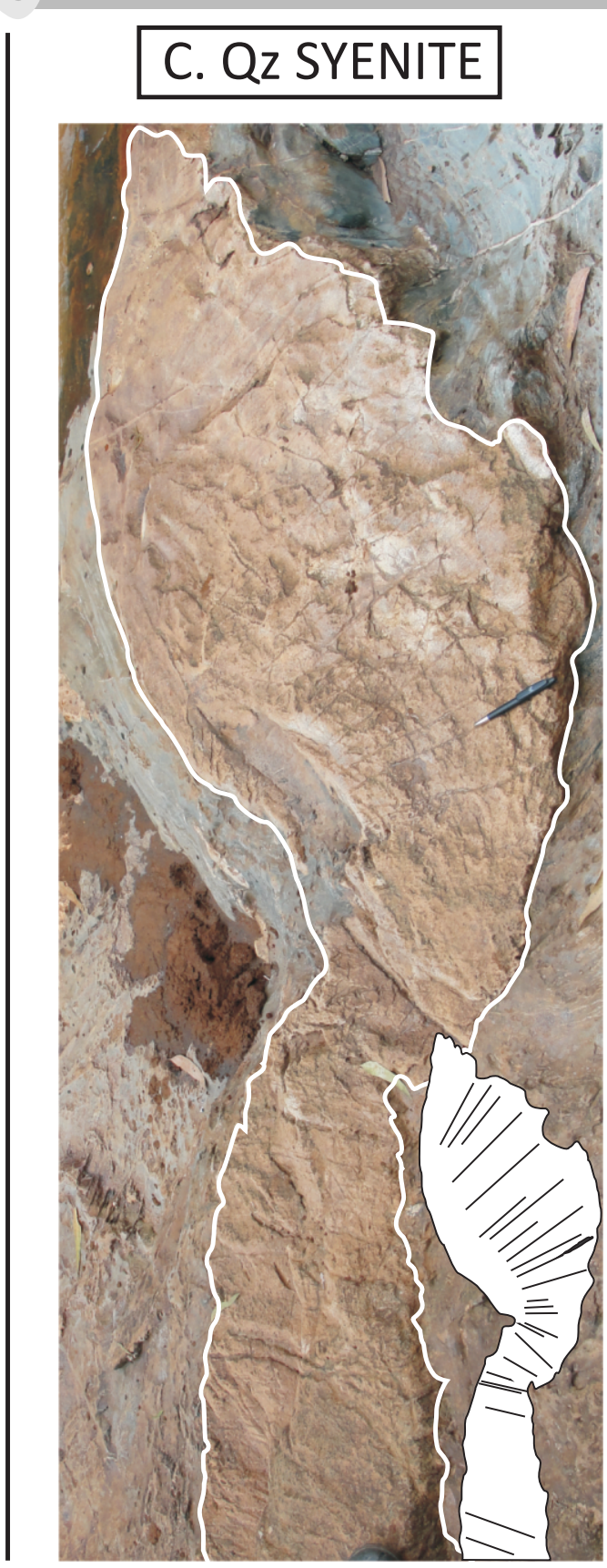




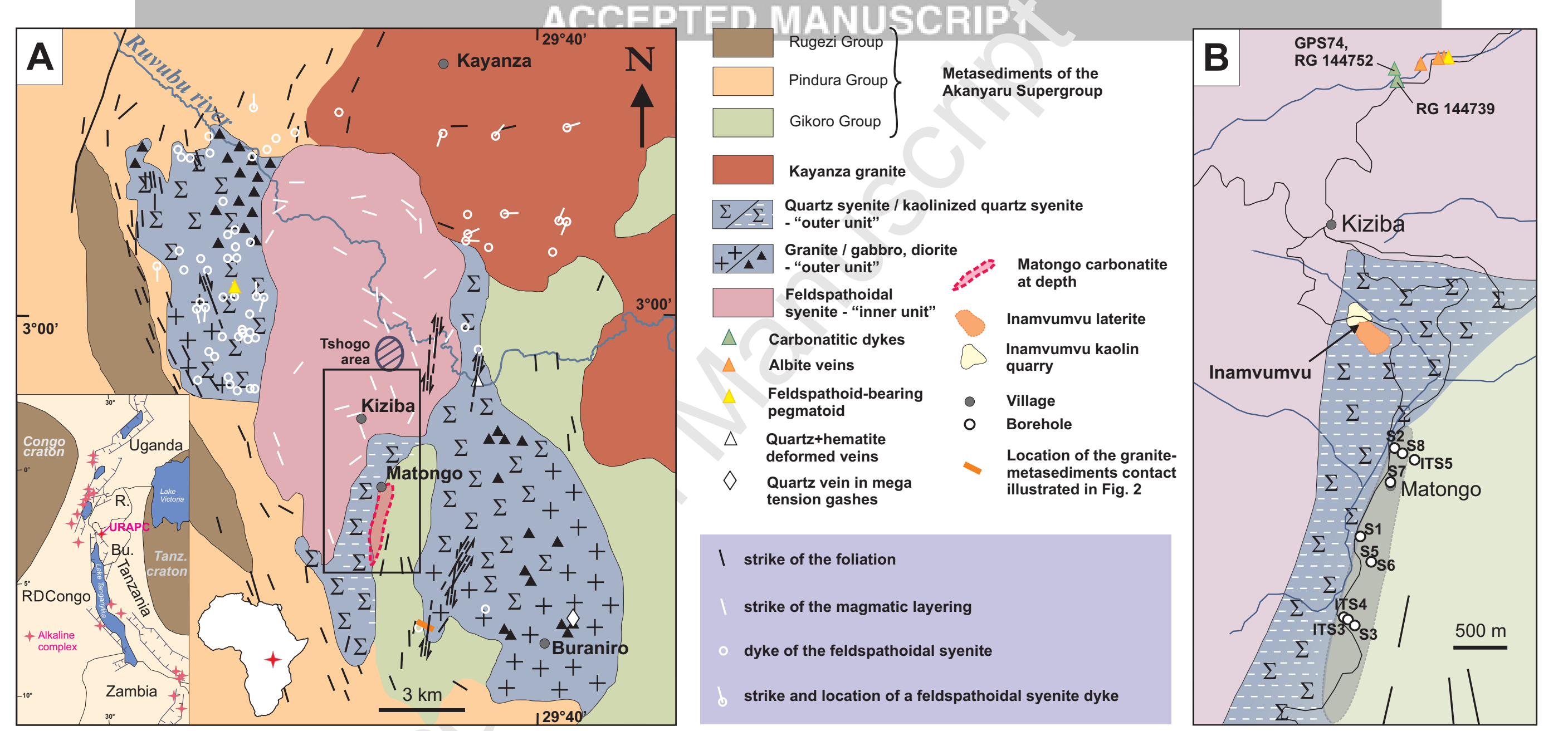

